\title{
Towards Reversible and Moisture Tolerant Aprotic Lithium-Air Batteries
}

Israel Temprano, Tao Liu, Enrico Petrucco, James H. J. Ellison, Gunwoo Kim, Erlendur Jónsson, Clare Grey

Submitted date: 30/04/2020 Posted date: 05/05/2020

Licence: CC BY-NC 4.0

Citation information: Temprano, Israel; Liu, Tao; Petrucco, Enrico; Ellison, James H. J.; Kim, Gunwoo; Jónsson, Erlendur; et al. (2020): Towards Reversible and Moisture Tolerant Aprotic Lithium-Air Batteries. ChemRxiv. Preprint. https://doi.org/10.26434/chemrxiv.12221717.v1

The development of moisture-tolerant, $\mathrm{LiOH}$-based non-aqueous $\mathrm{Li}-\mathrm{O}_{2}$ batteries is a promising route to

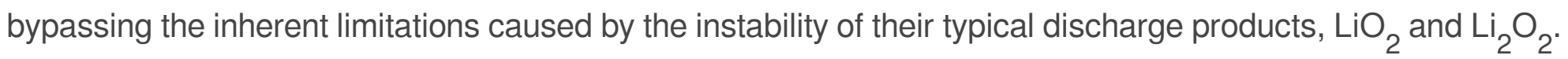
The use of the $\mathrm{I}^{-} / \mathrm{I}_{3}^{-}$redox couple to mediate the $\mathrm{LiOH}$-based oxygen reduction and oxidation reactions has proven challenging to develop due to the multiple reaction paths induced by the oxidation of $\mathrm{I}^{-}$on cell charging. In this work we demonstrate a reversible $\mathrm{LiOH}$-based $\mathrm{Li}-\mathrm{O}_{2}$ battery cycling through a $4 \mathrm{e}^{-} / \mathrm{O}_{2}$ process with low charging overpotential (below $3.5 \mathrm{~V}$ vs Li/ $\mathrm{Li}^{+}$) by introducing an ionic liquid to a glyme-based electrolyte containing Lil and water. The addition to the ionic liquid increases the oxidizing power of $\mathrm{I}_{3}{ }^{-}$, shifting the charging mechanism from $\mathrm{IO}^{-} / \mathrm{IO}_{3}^{-}$formation to $\mathrm{O}_{2}$ evolution

File list (5)

Towards reversible and moisture tolerant aprotic lithium-... (600.53 KiB) view on ChemRxiv • download file TOC.jpg (55.04 KiB) view on ChemRxiv • download file TOC.png (200.33 KiB) view on ChemRxiv • download file

SI Towards reversible and moisture tolerant aprotic lithiu... (700.98 KiB) view on ChemRxiv • download file TOC.bmp (1.40 MiB) view on ChemRxiv • download file 


\title{
Towards reversible and moisture tolerant aprotic lithium-air batteries
}

\author{
Israel Temprano ${ }^{1}$, Tao Liu ${ }^{1,2}$, Enrico Petrucco ${ }^{3}$, James H. J. Ellison ${ }^{1}$, Gunwoo Kim ${ }^{1}$, Erlendur \\ Jónsson ${ }^{1,4}$ \& Clare P. Grey*1
}

1 Department of Chemistry, University of Cambridge, Cambridge, UK

2 Current address: Shanghai Key Laboratory of Chemical Assessment and Sustainability, Department of Chemistry, Tongji University, Shanghai, China

3 Johnson Matthey, Blounts Court, Sonning Common, Reading, RG4 9NH, UK

4 Department of Physics, Chalmers University of Technology, Gothenburg, Sweden

\begin{abstract}
The development of moisture-tolerant, $\mathrm{LiOH}$-based non-aqueous $\mathrm{Li}^{-\mathrm{O}_{2}}$ batteries is a promising route to bypassing the inherent limitations caused by the instability of their typical discharge products, $\mathrm{LiO}_{2}$ and $\mathrm{Li}_{2} \mathrm{O}_{2}$. The use of the $1 / \mathrm{I}_{3}{ }^{-}$redox couple to mediate the $\mathrm{LiOH}$-based oxygen reduction and oxidation reactions has proven challenging to develop due to the multiple reaction paths induced by the oxidation of $\mathrm{I}$ on cell charging. In this work we demonstrate a reversible LiOH-based $\mathrm{Li}-\mathrm{O}_{2}$ battery cycling through a $4 \mathrm{e}-/ \mathrm{O}_{2}$ process with low charging overpotential (below $3.5 \mathrm{~V}$ vs Li/Li+) by introducing an ionic liquid to a glyme-based electrolyte containing Lil and water. The addition to the ionic liquid increases the oxidizing power of $\mathrm{I}_{3}{ }^{-}$, shifting the charging mechanism from $10^{-} / 1 \mathrm{O}_{3}^{-}$formation to $\mathrm{O}_{2}$ evolution.
\end{abstract}

In the light of recent commitments from several European countries to ban the sale of internal combustion engine vehicles in the coming decades [1,2], the race to develop electrical storage strategies beyond the capabilities of lithium ion batteries is intensifying considerably. Amongst the many different options, Li-air batteries have attracted significant attention due to their comparable energy density to fossil fuels [3].

Non-aqueous Li-air batteries (LABs) are composed of a lithium metal anode, an organic-based lithium-ion conducting liquid electrolyte, and a porous, typically carbon based, cathode. During discharge, $\mathrm{O}_{2}$ is reduced at the cathode (the oxygen reduction reaction, ORR), which then combines with lithium ions in solution forming insoluble discharge products that fill up the porous structure of the carbon electrode. The discharge product is oxidised during charge, with $\mathrm{O}_{2}$ being released back to the atmosphere (the oxygen evolution reaction, OER) [4].

Despite of its potential, several fundamental challenges remain to be overcome for the successful development of non-aqueous LABs [4-6]. Amongst these challenges, the instability of the typical discharge products $\left(\mathrm{LiO}_{2}\right.$ and $\left.\mathrm{Li}_{2} \mathrm{O}_{2}\right)$ in the presence of moisture and $\mathrm{CO}_{2}$ represents a fundamental stumbling block for their development [7]. Recently, it has been shown that lithium hydroxide (LiOH) can be formed as a discharge product in moisture-tolerant LABs with a high capacity and low charge overpotential using either Lil as a redox mediator or Ru as a catalyst in a wet organic electrolyte [810]. However, several questions surrounding the reversibility of $\mathrm{LiOH}$ chemistry remain, which arise from (i) the half-cell potential of the OER of $\mathrm{LiOH}$ under standard state (aqueous) conditions being higher than that of the $\mathrm{Li}_{2} \mathrm{O}_{2}$ OER, given the higher thermodynamic stability of the former, (ii) the detection of oxidation products originating from the redox mediator and the solvents, such as $\mathrm{IO}_{3}{ }^{-}$ $[9,11,12]$, and $\mathrm{DMSO}_{2},[10]$ respectively, after charge (iii) little or no oxygen evolution being observed in gas analysis experiments [12]. These observations have given rise to doubts as to whether the 
iodide/triiodide $\left(\mathrm{I}^{-} / \mathrm{I}_{3}{ }^{-}\right)$redox system is capable of sustaining reversible ORR/OER chemistry via LiOH formation and decomposition [12-15].

It is now established that the $\left(\mathrm{I}^{-} / \mathrm{I}_{3}^{-}\right)$redox potential is solvent-dependent, and therefore that the oxidizing power of $\mathrm{I}_{3}^{-}$can be tailored by means of adjusting the physicochemical parameters (i.e., dielectric constant, ionic strength, Gutmann acceptor/donor numbers, etc.) of the electrolyte $[9,16-$ 18]. Ionic liquids (IL) have been shown to alter the solvation/coordination environments of this redox system, therefore substantially affecting the $\left(\mathrm{I}^{-} / \mathrm{I}_{3}{ }^{-}\right)$redox potential [16], while combining high ionic conductivity with low volatility [19-26]. However, the high viscosity of ILs, which limits $\mathrm{O}_{2}$ diffusion coefficients, and the low $\mathrm{O}_{2}$ solubility are disadvantageous for the performance of LABs [27]. The presence of water has been shown to help addressing some of these drawbacks by enhancing the solution-transfer of discharge products and redox mediator [28], and by affecting the solvation coordination of the electrolyte, which has also shown to have an impact in the activity of the $\left(1 / l_{3}{ }^{-}\right)$ redox system during discharge [8]. Thus, the combination of Lil as redox mediator with water and an ionic liquid is a potentially good strategy for efficiently tailoring the electrolyte properties in $\mathrm{Li}^{-\mathrm{O}_{2}}$ batteries.

In this work we report a step forward toward the realization of a viable moisture tolerant $L A B$, by reversibly cycling $\mathrm{LiOH}$ with low charging overpotentials in cells with Lil as redox mediator and $\mathrm{H}_{2} \mathrm{O}$ and pyrrolidinium $(1,4)$ bis(trifluoromethanesulfonyl)imide ( $\mathrm{Pyr}_{14} \mathrm{TFSI}$ ) as additives in a low volatility electrolyte. Pyr ${ }_{14} \mathrm{TFSI}$ is one of the most widely studied ILs in relation to $\mathrm{Li}^{-\mathrm{O}_{2}}$ batteries, showing high stability toward superoxide species, and a relatively high $\mathrm{Li}^{+}$diffusion coefficient [22,26-31]. We found that the inclusion of $\mathrm{Pyr}_{14} \mathrm{TFSI}$ is crucial for the reversibility of the electrochemical formation/decomposition of $\mathrm{LiOH}$ as demonstrated by the observation of a 4 e $/ \mathrm{O}_{2}$ OER using operando online electrochemical mass spectrometry (OEMS). OER from LiOH decomposition is further confirmed by OEMS experiments with (electrochemically) preloaded electrodes, as well as isotopic labelling. The suppression of the side-reactions to form oxygenated iodine species $\left(\mathrm{IO}^{-}, \mathrm{IO}_{3}{ }^{-}\right)$, which trap the oxygen during charge is also observed.

\section{A $4 \mathrm{e} / \mathrm{O}_{2}$ oxygen evolution reaction}

$\mathrm{Li}-\mathrm{O}_{2}$ cells were constructed with a lithium metal anode, an anolyte consisting of $0.3 \mathrm{M} \mathrm{LiTFSI}$ in $\mathrm{G} 4$, a lithium conducting glass ceramic (LICGC-Ohara AG010) separating the two electrolytes, a catholyte containing $0.9 \mathrm{M} \mathrm{Pyr}_{14} \mathrm{TFSI}, 0.7 \mathrm{M}$ LiTFSI, $50 \mathrm{mM}$ Lil and $5000 \mathrm{ppm} \mathrm{H}_{2} \mathrm{O}$ in $\mathrm{G} 4$, and a mesoporous carbon black cathode (Ensaco-P150). The LICGC serves to prevent redox shuttling $\left(\mathrm{I}^{1} / \mathrm{I}_{3}{ }^{-}\right)$and reaction of catholyte additives with the $\mathrm{Li}$ anode. These cells were evaluated with operando OEMS by capacity-limiting galvanostatic cycling, in order to keep the levels of water within limits known for promoting LiOH formation during the ORR (between 1500 and 5000 ppm). Fig. 1 (system description in Supplementary Fig. 1a) shows the electrochemical profile $(a, b)$ and gas evolution rate of $\mathrm{O}_{2}$ $(\mathrm{m} / \mathrm{z}=32 ; \mathrm{c}, \mathrm{d}), \mathrm{H}_{2}, \mathrm{CO}$ and $\mathrm{CO}_{2}(\mathrm{~m} / \mathrm{z}=2,28,44 ; \mathrm{e}, \mathrm{f})$ for the discharge and charge of this cell. The electrochemical discharge profile (Fig. 1a) shows a sustained single discharge plateau at $2.6 \mathrm{~V}$ (vs $\mathrm{Li} / \mathrm{Li}^{+}$). The discharge produces a constant consumption rate of oxygen of $\sim 0.51 \mathrm{nmol} / \mathrm{s}$ (Fig. 1c), corresponding to a $4 \mathrm{e} / \mathrm{O}_{2}$ stoichiometry, with no significant evolution of gases indicative of parasitic reactions (Fig. 1e). The total amount of oxygen consumption detected amounts to $18.5 \mu \mathrm{mol}$, which corresponds to a $99.1 \%$ Faradaic efficiency. 

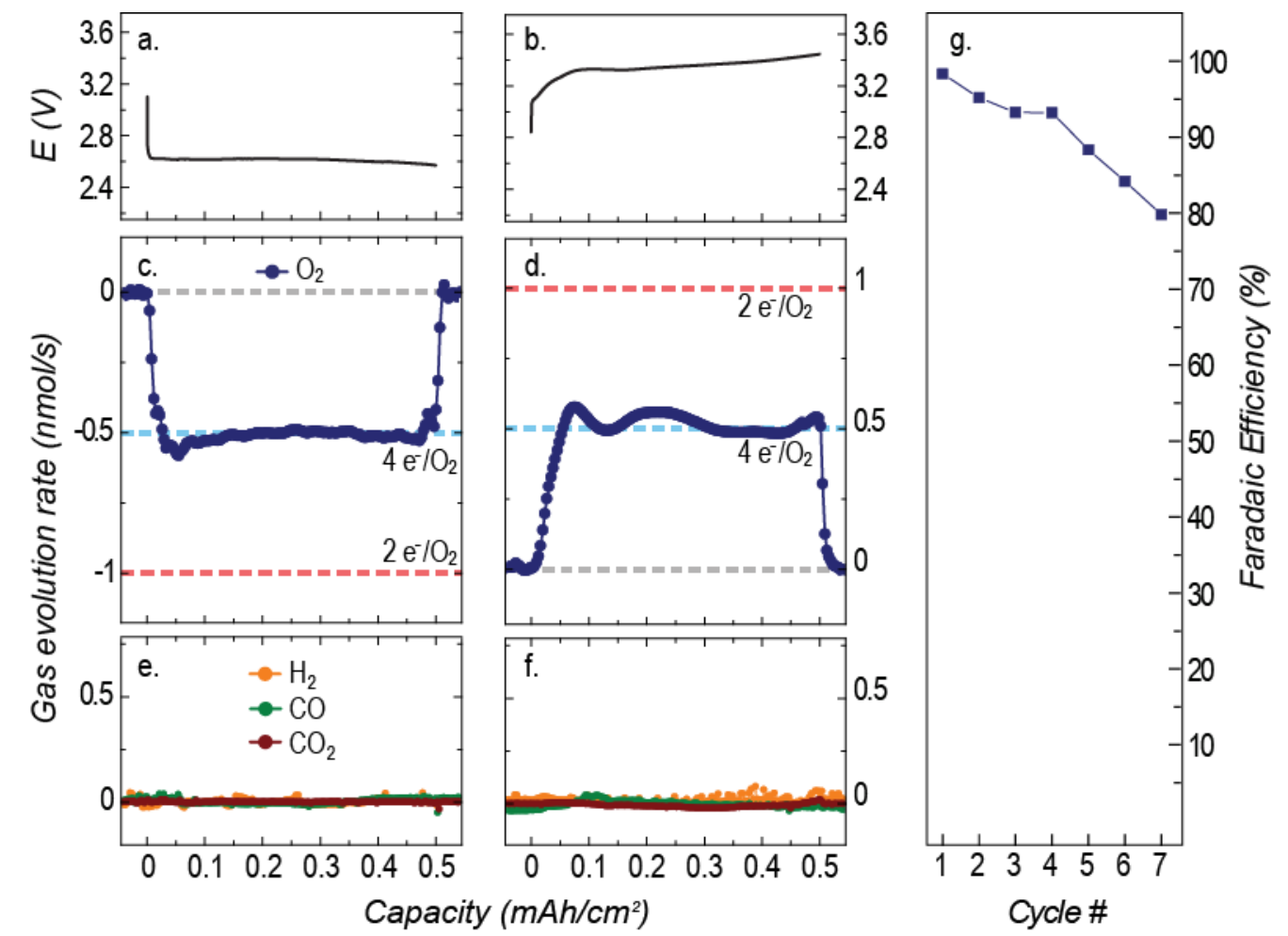

Figure 1| 4 Electron Formation and Removal of LiOH in Mixed Glyme/lonic Liquid Cells. a, b, Galvanostatic profiles and $\mathbf{c}$, $\mathbf{d}$, online mass spectrometry analysis of oxygen, and $\mathbf{e}$, $\mathbf{f}$, hydrogen, carbon monoxide and carbon dioxide $(\mathrm{m} / \mathrm{z}=32,2,28,44$ respectively) evolution of batteries discharged (left) and charged (right) at a current of $50 \mu \mathrm{A} / \mathrm{cm}^{2}$ in an electrolyte comprising $0.9 \mathrm{M}$ $\mathrm{Pyr}_{14}$ TFSI, $0.7 \mathrm{M} \mathrm{LiTFSI}, 50 \mathrm{mM}$ Lil and 5000 ppm $\mathrm{H}_{2} \mathrm{O}$ in G4; g, Faradaic efficiency of the OER during the first 7 cycles.

The charge profile shows an initial rapid increase in potential from 3.1 to $3.3 \mathrm{~V}$ followed by a relatively flat process at approximately $3.4 \mathrm{~V}$ (Fig. 1b). Of note, oxygen evolution is clearly observed to occur from the beginning of charge, stabilising around a rate corresponding to approximately $4 \mathrm{e}^{-}$ $/ \mathrm{O}_{2}$ stoichiometry (Fig. $1 \mathrm{~d}$ ). A total of $18.4 \mu$ moles of oxygen evolved during charge, $99.5 \%$ of the amount consumed in the discharge, with no significant signs of parasitic reactions as signalled by a lack of evolution of $\mathrm{H}_{2}, \mathrm{CO}$ or $\mathrm{CO}_{2}$ (Fig. 1d). The Faradaic efficiency decreases steadily in subsequent discharge-charge cycles, although it remains above $80 \%$ after 7 cycles (Fig. 1g, and Supplementary Fig. 2). This indicates incomplete removal of $\mathrm{LiOH}$, a small degree of degradation and/or accumulation of products from parasitic reactions.

By comparison, in the absence of $\mathrm{Pyr}_{14} \mathrm{TFSI}$ only a very small amounts of oxygen ( $\left.0.4 \mathrm{nmol} / \mathrm{s}\right)$ above $3.5 \mathrm{~V}$, and hydrogen $(<0.2 \mathrm{nmol} / \mathrm{s})$ are detected (Supplementary Fig. $3 \mathrm{~g}-\mathrm{m})$ during charge before a steep increase in potential above $3.6 \mathrm{~V}$ at the end of charge is observed, which is accompanied by a significant evolution of carbon dioxide (and to carbon monoxide to lesser extent), suggesting electrode (carbon)/electrolyte oxidation (Supplementary Fig. 3m).

\section{Analysis of the ORR products}

Analysis of the cathode after discharge with X-ray diffraction (XRD) (Fig. 2a - red trace) is dominated by patterns corresponding to crystalline $\mathrm{LiOH}$. All reflections associated to $\mathrm{LiOH}$ are absent in the 
diffractogram corresponding to the fully charged electrodes, confirming the removal of the crystalline discharge product. (Fig. 2a-green trace).

Operando pressure monitoring during discharge (Fig. $2 \mathrm{~b}$ ) confirms a 4 e $/ \mathrm{O}_{2}$ stoichiometry during ORR for cells with $\mathrm{Pyr}_{14} \mathrm{TFSI}$, as expected for the formation of $\mathrm{LiOH}$. The insert in Fig. $2 \mathrm{~b}$ shows a bar plot of the $\mathrm{LiOH}: \mathrm{Li}_{2} \mathrm{O}_{2}$ ratio (of $97: 3 \pm 3$ ) in the discharge product determined via an acid-base and iodometric titration [32] of the electrodes at the end of discharge. This suggests that the ORR reaction occurs almost in its entirety through the formation of $\mathrm{LiOH}$, and not through $\mathrm{Li}_{2} \mathrm{O}_{2}$ chemistry under the experimental conditions shown in Fig. 1.

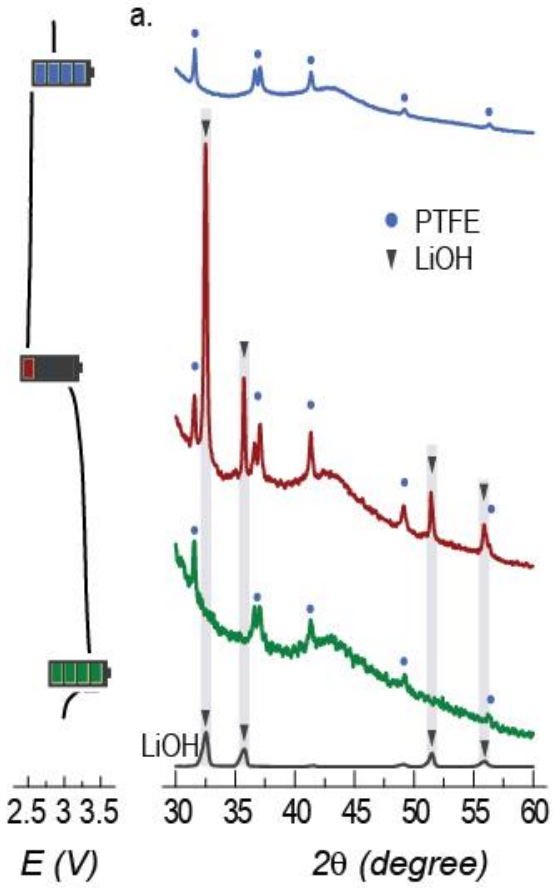

c.

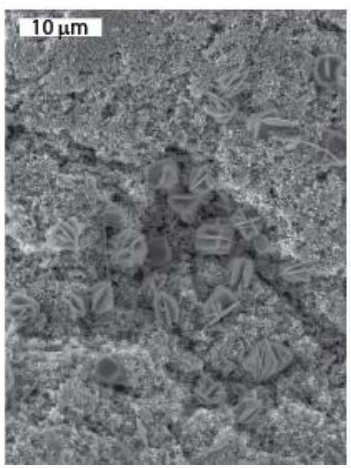

b.

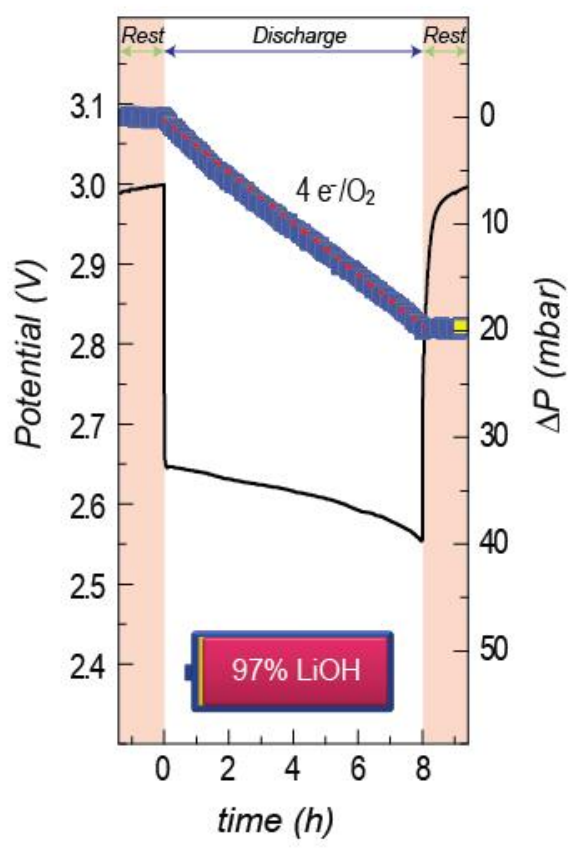

d.

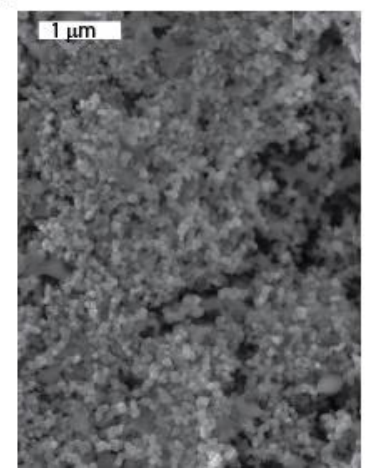

Figure 2| Operando and ex-situ characterization of the LiOH Formation during ORR. a, X-ray diffractograms at different stages of capacity-limited cycling (pristine - blue; discharged - red; fully charged - green) as represented in the electrochemical profile; $\mathbf{b}$, Operando pressure monitoring experiment during discharge and representation of the percentage of $\mathrm{LiOH}$ (magenta) and $\mathrm{Li}_{2} \mathrm{O}_{2}$ (orange) detected by titration measurements at the end of the discharge. (Note that the presence of $\mathrm{I}_{3}{ }^{-}$in the electrolyte generates an underestimation of $\mathrm{LiOH}$ and overestimation of $\mathrm{Li}_{2} \mathrm{O}_{2}$ as discussed in the methods section); SEM characterisation (at different magnifications) of electrodes at the end of discharge $\mathbf{c}$, and end of charge $\mathbf{d}$, (scale bars shown in white). Relevant reflections due to LiOH and PTFE binder are indicated by grey triangles and blue dots, respectively in a. All cells were cycled at 50 $\mu \mathrm{A} / \mathrm{cm}^{2}$. 
Scanning electron microscopy (SEM) images of electrodes during the first discharge are shown in Fig. 2c. The discharge product in capacity limited cells ( $2 \mathrm{mAh}$ ) present typical "flower-like" LiOH crystals, similar to those previously reported in cells containing Lil and water [9] of up to $7 \mu \mathrm{m}$ in size. The absence of these crystalline structures in the SEM images of fully recharged electrodes (Fig. 2d) confirms the removal of the discharge product during charge without the precipitation of large quantities of by-products from parasitic reactions.

In order to evaluate the mechanistic implications of the observed stoichiometry during the OER in Fig. 1, further OEMS experiments using an electrode either electrochemically preloaded with $\mathrm{Li}_{2} \mathrm{O}_{2}$ (Fig. 3 - left) or discharged with partially ${ }^{17} \mathrm{O}$-enriched $\mathrm{H}_{2} \mathrm{O}$ (Fig. 3 - right) were performed. $\mathrm{Li}_{2} \mathrm{O}_{2}$ preloaded electrodes were first produced by discharging a cell using $3 \mathrm{M} \mathrm{LiTFSI}$ in G4 as the electrolyte (i.e., with no Lil). The cell was subsequently disassembled in the glove box and the electrode was washed 3 times with DME and dried under vacuum for 30 minutes. This electrode was then loaded in a two-compartment cell with the same electrolyte (containing $0.9 \mathrm{M} \mathrm{Pyr}_{14} \mathrm{TFSI}, 0.7 \mathrm{M}$ LiTFSI, $50 \mathrm{mM}$ Lil and 5000 ppm $\mathrm{H}_{2} \mathrm{O}$ in G4) used for the cells shown in Fig. 1. In this case the OER showed an approximately $2 \mathrm{e} / \mathrm{O}_{2}$ stoichiometry (Fig. 3c) consistent with the reversible formation and oxidation of $\mathrm{Li}_{2} \mathrm{O}_{2}$. After reaching an evolution rate corresponding to $2 \mathrm{e} / \mathrm{O}_{2}$, a noticeable dip in the oxygen evolution is seen (Fig. 3c). This effect has been previously attributed to a transition between the delithiation of $\mathrm{Li}$-deficient $\left(\mathrm{Li}_{2-x} \mathrm{O}_{2}\right)$ species on $\mathrm{Li}_{2} \mathrm{O}_{2}$ particles [33-35]. Preloading was similarly performed using the IL-free conditions previously shown to produce $\mathrm{LiOH}$ electrochemically

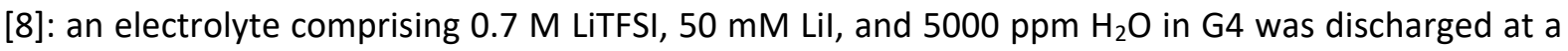
current of $70 \mu \mathrm{A} / \mathrm{cm}^{2}$. Switching to the ionic liquid containing electrolyte resulted in $4 \mathrm{e}-/ \mathrm{O}_{2}$, oxygen evolution on charge (Supplemental Figure 6), which indicates that the presence of the ionic liquid has only a limited effect in the formation of the discharge product.
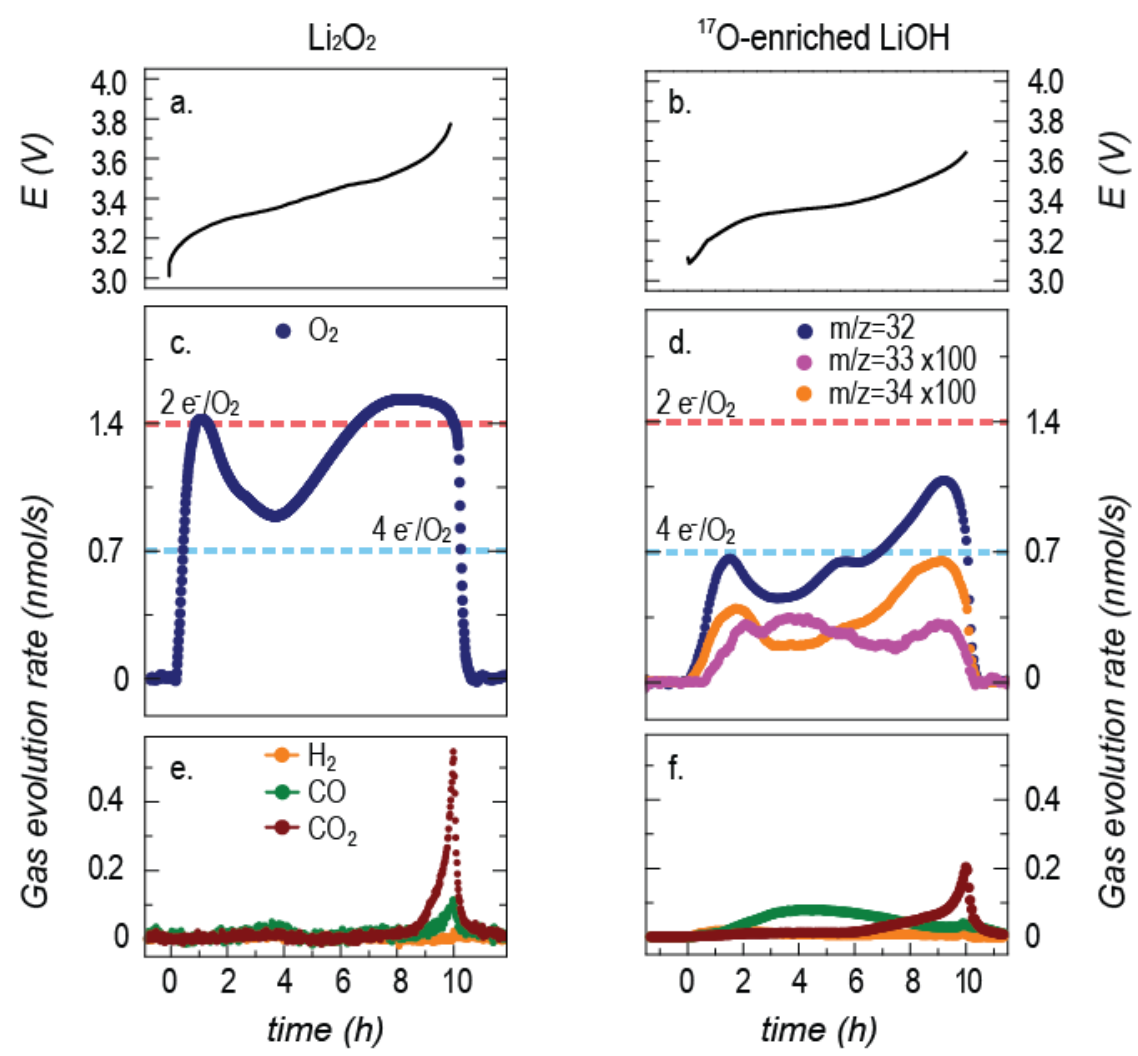

Figure 3| Operando Gas Analysis of Preloaded Electrodes and Isotopic Exchange during OER. a, b, Galvanostatic profiles (top) and $\mathbf{c}$, $\mathbf{d}$, online mass spectrometry analysis of oxygen $(\mathrm{m} / \mathrm{z}=32)$ and $\mathbf{e}, \mathbf{f}$, hydrogen, carbon monoxide and carbon dioxide $(\mathrm{m} / \mathrm{z}=2,28,44)$ evolution during charge of 
electrochemically preloaded electrodes with $\mathrm{Li}_{2} \mathrm{O}_{2}$ (left); and of a $\mathrm{Li}_{-} \mathrm{O}_{2}$ cell discharged using ${ }^{17} \mathrm{O}$ enriched $\mathrm{H}_{2} \mathrm{O}$ in the electrolyte containing $\mathrm{G} 4$ and $\mathrm{Pyr}_{14} \mathrm{TFSI}$ at $70 \mu \mathrm{A} / \mathrm{cm}^{2}$.

Since earlier ${ }^{17} \mathrm{O}$-ssNMR measurements have reported that both $\mathrm{O}_{2}$ and $\mathrm{H}_{2} \mathrm{O}$ contribute to the oxygen atoms in the LiOH formed via a Lil-catalysed electrochemical reaction in DME (G1), [8], a further OEMS experiment was performed using ${ }^{17} \mathrm{O}$-enriched $\mathrm{H}_{2} \mathrm{O}$ (Fig. 3 - right) and $\mathrm{Pyr}_{14}$ TFSI. A $\mathrm{m} / \mathrm{z}=32$ mass spectrometer signal (Fig. $3 \mathrm{~d}$ - blue) dominates the response on charge, which is due to ${ }^{16} \mathrm{O}-{ }^{16} \mathrm{O}$. A signal is seen at $\mathrm{m} / \mathrm{z}=33$ (Fig. $3 \mathrm{~d}-$ magenta), which is assigned to ${ }^{17} \mathrm{O}-{ }^{16} \mathrm{O}$. The signal at $\mathrm{m} / \mathrm{z}=34$ (Fig. $3 \mathrm{~d}$ - orange) is assigned to either to ${ }^{17} \mathrm{O}-{ }^{17} \mathrm{O}$ or ${ }^{18} \mathrm{O}-{ }^{16} \mathrm{O}$. Since the signal intensity of the $\mathrm{m} / \mathrm{z}=33$ and 34 signals are similar in magnitude, this indicates that the $\mathrm{m} / \mathrm{z}=33$ signal is not due to the ${ }^{17} \mathrm{O}$ in $\mathrm{O}_{2}$ gas, since the natural abundance of ${ }^{17} \mathrm{O}$ and ${ }^{18} \mathrm{O}$ are 0.04 and $0.2 \%$, respectively. The relatively low intensity of the $\mathrm{m} / \mathrm{z}=33$ signal (from ${ }^{16} \mathrm{O}-{ }^{17} \mathrm{O}$ ) compared with the $\mathrm{m} / \mathrm{z}=32$ signal (from ${ }^{16} \mathrm{O}-{ }^{16} \mathrm{O}$ ) is due to the low ${ }^{17} \mathrm{O}$-enrichment in the $\mathrm{LiOH}$ as observed by ${ }^{17} \mathrm{O}$ ssNMR (Supplementary Fig. 6), most likely a result of the low enrichment of the $\mathrm{H}_{2}{ }^{17} \mathrm{O}$.

\section{Pathways to LiOH removal}

The mechanism for LiOH formation in the ORR reaction have been discussed extensively elsewhere [8] and thus we focus here on the OER reaction. Two questions arise from the OEMS data (Fig. 1 and Supplementary Figs. S2, S10, and S11). Firstly, what is the role played by $\mathrm{Pyr}_{14} \mathrm{TFSI}$ in the promotion of oxygen evolution? Secondly, what is the mechanism for LiOH decomposition/removal in the absence of the ionic liquid when there is no $\mathrm{O}_{2}$ evolution?

The Lil mediated OER during the charge of $\mathrm{LiOH}$-based $\mathrm{Li}^{-} \mathrm{O}_{2}$ batteries has been proposed to follow a two-step path where the electrochemical oxidation of $\mathrm{I}^{-}$to $\mathrm{I}_{3}{ }^{-}$is followed by the chemical oxidation of LiOH $[8-10,12,36,37]$

$3 \mathrm{I}^{-} \leftrightarrows \mathrm{I}_{3}^{-}+2 \mathrm{e}^{-}$

$4 \mathrm{OH}^{-}+2 \mathrm{I}_{3}^{-} \leftrightarrows 2 \mathrm{H}_{2} \mathrm{O}+6 \mathrm{I}^{-}+\mathrm{O}_{2}$

where $E_{v s}^{o} L_{i / L i}{ }^{+}$for reaction (1) corresponds to $3.5761 \mathrm{~V}$ under standard (aqueous) conditions. The reversibility of $\mathrm{Li}_{-} \mathrm{O}_{2}$ batteries cycling through $\mathrm{LiOH}$ has been a much-discussed subject due to the high thermodynamic stability of $\mathrm{LiOH}$ and the difficulty of performing the multi electron OER process at low overpotentials $[9-12,14,15,37,38]$.

The potential under standard conditions of the $1 / \mathrm{I}_{3}{ }^{-}$equilibrium is very close to the redox potential of the $\mathrm{I}^{-} / \mathrm{I}_{2}$ equilibrium $\left(E_{\mathrm{vs}}^{\mathrm{O} L / / \mathrm{L}^{+}}=3.5756 \mathrm{~V}\right)$

$2 \mathrm{I}^{-} \leftrightarrows \mathrm{I}_{2}+2 \mathrm{e}^{-}$

and in water only a single process is seen in CV scans at close to $3.6 \mathrm{~V}$, indicating that both $\mathrm{I}_{3}{ }^{-}$and $\mathrm{I}_{2}$ are thermodynamically capable of decomposing $\mathrm{LiOH}$ to generate $\mathrm{O}_{2}$ under standard conditions (the $2 \mathrm{LiOH} /\left(\mathrm{O}_{2}+\mathrm{H}_{2} \mathrm{O}\right)$ couple corresponding to $\left.3.34 \mathrm{~V}\right)[16]$.

The removal of $\mathrm{LiOH}$ upon charging in cells containing Lil in organic electrolytes with added water has been shown to produce $\mathrm{IO}_{3}{ }^{-}$as the dominant product rather than $\mathrm{O}_{2}$ at $\sim 3.5 \mathrm{~V}$ in ether based electrolytes $[11,12]$, which has been proposed to form through the oxidation of $I^{-}$to $I_{2}$ (reaction 3 ) and its subsequent chemical reaction with $\mathrm{LiOH}$ [12]:

$3 \mathrm{I}_{2}+6 \mathrm{OH}^{-} \leftrightarrows \mathrm{IO}_{3}^{-}+5 \mathrm{I}^{-}+3 \mathrm{H}_{2} \mathrm{O}$

or via direct oxidation by $\mathrm{I}_{3}{ }^{-}[11,38]$ :

$\mathrm{I}_{3}^{-}+2 \mathrm{OH}^{-} \leftrightarrows 2 \mathrm{I}^{-}+\mathrm{H}_{2} \mathrm{O}+1 \mathrm{O}^{-}$ 
followed by the disproportionation of $1 \mathrm{IO}^{-}$into $\mathrm{IO}_{3}^{-}[11,17,38]$.

$310^{-} \leftrightarrows 2 \mathrm{I}^{-}+\mathrm{IO}_{3}^{-}$

In this study, cells containing $\mathrm{Pyr}_{14} \mathrm{TFSI}$ show clear evidence for a 4 e $/ \mathrm{O}_{2}$ OER commencing at $\sim 3.2 \mathrm{~V}$ (Fig. 1). This oxygen evolution is absent in cells without ionic liquid (Supplementary Fig. 3 e-h) even when charging at comparable potentials (below $3.5 \mathrm{~V}$ for $\sim 75 \%$ of charge). In order to investigate the difference in mechanism during the OER, characterization of the electrolyte after charge was performed. UV spectra of aliquots of the electrolyte of charged cells with and without $\mathrm{Pyr}_{14} \mathrm{TFSI}$ (Fig. 4b) show the presence of features at 295 and $365 \mathrm{~nm}$, corresponding to the presence of $\mathrm{I}_{3} ;$; no feature corresponding to $I_{2}$ (at $520 \mathrm{~nm}$ ) is seen in either case (insert in Fig. 4b). The electrolyte of cells without IL (Fig. $4 \mathrm{~b}-$ red trace) show the presence of peaks at 228 and $465 \mathrm{~nm}$, assigned to $\mathrm{IO}_{3}{ }^{-}$

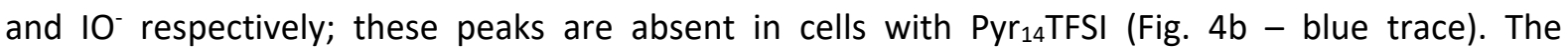
presence of $\mathrm{I}_{3}{ }^{-}$in both samples indicates that this is the main product of $\mathrm{I}^{-}$oxidation, and therefore suggest that this may be the species responsible for oxidising $\mathrm{LiOH}$, rather than $\mathrm{I}_{2}$. The lack of $\mathrm{O}_{2}$ evolution observed in OER data of cells without Pyr ${ }_{14}$ TFSI can be explained by the formation of oxidized iodine species $\left(\mathrm{IO}^{-}\right.$and $\left.\mathrm{IO}_{3}{ }^{-}\right)$the oxygen effectively being trapped in the solution, as reported for similar electrolytes $[11-13,17,38]$.

In order to test these hypotheses, a solution of $\mathrm{I}_{3}{ }^{-}$was injected into a mixture of electrolyte containing $0.9 \mathrm{M} \mathrm{Pyr}_{14} \mathrm{TFSI}, 0.7 \mathrm{M}$ LiTFSI, $50 \mathrm{mM}$ Lil and 5000 ppm $\mathrm{H}_{2} \mathrm{O}$ in G4, and commercial LiOH powder, and the gas evolution measured by mass spectrometry (Fig. 4a). Gas bubbles can be seen evolving from the $\mathrm{LiOH}$ powder as soon as the $\mathrm{I}_{3}{ }^{-}$solution is injected and the $\mathrm{m} / \mathrm{z}=32$ signal confirms the evolution of $\mathrm{O}_{2}$ from this mixture, demonstrating that $\mathrm{I}_{3}{ }^{-}$is capable of oxidizing $\mathrm{LiOH}$, as per reaction (2), in this electrolyte.

Solvation effects can strongly influence the electrochemistry of soluble redox mediators by altering thermodynamics and reactivity of the mediators. In particular, the oxidising power of $\mathrm{I}_{3}{ }^{-}$has been shown to depend on the solvation/coordination properties of the electrolyte $[8,17,18]$. Increasing the thermodynamic stability of I' through solvation, e.g. by including additives with large Gutmann acceptor numbers (AN) and dielectric constants, has been proposed to decrease the equilibrium constant in reaction 1 , driving the reaction to the left (towards $\mathrm{I}^{-}$) and promoting an increase in the oxidising power of $\mathrm{I}_{3}{ }^{-}$[16-18]. More generally, the factors that control the relative and absolute values of the two couples are subtle, because the values are also controlled by the stability of $\mathrm{I}_{3}{ }^{-}$ relative to $I_{2}+I^{-}$, as defined by the following disproportionation reaction:

$\mathrm{I}_{3}^{-} \leftrightarrows \mathrm{I}_{2}+\mathrm{I}^{-}$

As the stability of $\mathrm{I}_{3}{ }^{-}$decreases then distinct redox process for reactions 1 and 3 are no longer seen. For example, in water, where $\mathrm{I}^{-}$is strongly solvated and $\mathrm{I}_{2}$ is only sparingly soluble, only one process is seen, while in acetonitrile, with its lower acceptor number (and thus weaker coordination to $I^{-}$), the two processes are separated by $0.4 \mathrm{~V}[16]$. 

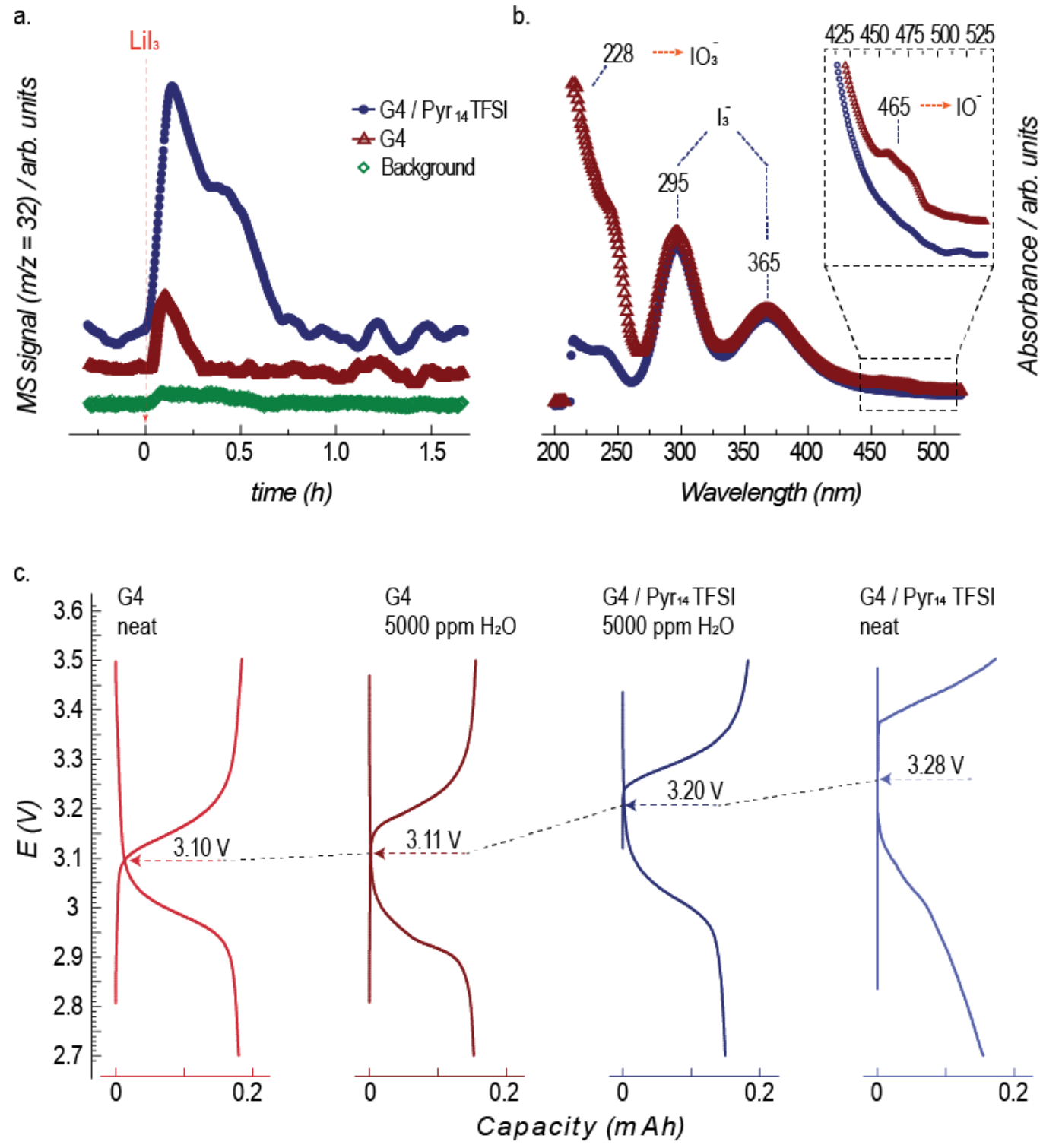

Figure $4 \mid$ Spectroscopic and electrochemical analysis of the $\mathrm{I}_{3}{ }^{-}$oxidising power. a, Online mass spectrometry chemical test. At $\mathrm{t}=0,0.2 \mathrm{ml}$ of a $50 \mathrm{mM} \mathrm{I}_{3}{ }^{-}, 0.9 \mathrm{M} \mathrm{Pyr}{ }_{14} \mathrm{TFSI}$ solution in $\mathrm{G} 4$ is injected to $10.5 \mathrm{mg}$ of $\mathrm{LiOH}$ in $0.5 \mathrm{ml}$ of electrolyte containing $0.9 \mathrm{M} \mathrm{Pyr}{ }_{14} \mathrm{TFSI}, 0.7 \mathrm{M} \mathrm{LiTFSI}, 50 \mathrm{mM}$ Lil, 5000 ppm $\mathrm{H}_{2} \mathrm{O}$ in $\mathrm{G} 4$ (blue trace) and $0.7 \mathrm{M} \mathrm{LiTFSI}, 50 \mathrm{mM}$ Lil, 5000 ppm $\mathrm{H}_{2} \mathrm{O}$ in $\mathrm{G} 4$ (red trace). A blank spectrum is collected by injecting the $\mathrm{I}_{3}^{-}$solution into the electrolyte containing $0.9 \mathrm{M} \mathrm{Pyr}{ }_{14} \mathrm{TFSI}, 0.7$ $\mathrm{M}$ LiTFSI, $50 \mathrm{mM}$ Lil, 5000 ppm $\mathrm{H}_{2} \mathrm{O}$ in $\mathrm{G} 4$ in the absence of LiOH (green trace). Argon was used as carrier gas; $\mathbf{b}$, UV spectra of catholytes collected after galvanostatic discharge and charge $(0.7$

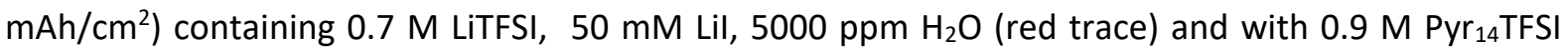
(blue trace) in G4; c, Galvanostatic charge-discharge curves of catholytes with $0.7 \mathrm{M}$ LiTFSI, $50 \mathrm{mM}$ Lil in neat $\mathrm{G} 4$ (light red) and $\mathrm{G} 4$ containing 5000 ppm $\mathrm{H}_{2} \mathrm{O}$ (dark red) and with neat $0.9 \mathrm{M}$ Pyr14TFSI (light blue) and $\mathrm{Pyr}_{14} \mathrm{TFSI}$ containing 5000 ppm $\mathrm{H}_{2} \mathrm{O}$ (dark blue), cycled at $50 \mu \mathrm{A} / \mathrm{cm}^{2}$ under argon. A LICGC isolated the cathode from the Li metal anode; $0.3 \mathrm{M} \mathrm{LiTFSI} \mathrm{in} \mathrm{G4} \mathrm{was} \mathrm{used} \mathrm{as} \mathrm{the} \mathrm{anolyte.}$

Galvanostatic charge-discharge curves of cells cycled under argon atmosphere show that the $1 / \mathrm{I}_{3}{ }^{-}$

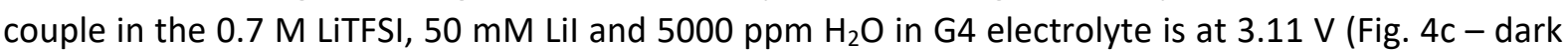
red trace and Supplementary Fig. S9a), slightly above of the value observed for the same neat electrolyte (0.7 M LiTFSI, $50 \mathrm{mM}$ Lil in G4) of $3.10 \mathrm{~V}$ (Fig. 4c - light red trace). These values are also slightly above the ones reported for cells with $0.25 \mathrm{M} \mathrm{LiTFSI,} 50 \mathrm{mM} \mathrm{Lil,} 5000$ ppm $\mathrm{H}_{2} \mathrm{O}$ in $\mathrm{G} 4$ and G1 
of 3.07 $\mathrm{V}$ and $2.95 \mathrm{~V}$ respectively [9]. The addition of $\mathrm{Pyr}_{14} \mathrm{TFSI}$ to these mixtures increases the $1 / \mathrm{I}_{3}{ }^{-}$ redox potential to $3.20 \mathrm{~V}$ and $3.28 \mathrm{~V}$ in the wet and neat electrolytes respectively (Fig. $4 \mathrm{c}-$ dark and light blue traces and Supplementary Fig. S9a). The $\mathrm{I} / \mathrm{I}_{2}$ redox potential is found above $3.7 \mathrm{~V}$ and $3.8 \mathrm{~V}$ in the absence and presence of $\mathrm{Pyr}_{14} \mathrm{TFSI}$, respectively (Supplementary Fig. S9a), with the large separation between the two iodine couples being ascribed to the poor solvation of $I_{2}$ by glymes $[16,18]$. This is consistent with previous work where the higher oxidative power of $I_{2}$ and $I_{3}{ }^{-}$in pure ILs than in solvents such as acetonitrile was ascribed to the higher ionic strength of the ionic liquids, which stabilizes $\mathrm{I}^{-}$(and $\mathrm{I}_{3}{ }^{-}$to a lesser extent) and their poor ability to solubilise $\mathrm{I}_{2}$. The addition of water impurities to the ILs was shown to increase the oxidising power of $\mathrm{I}_{3}{ }^{-}$, while the addition of solvents that solvate $I_{2}$ lowers the value of the $I_{3}{ }^{-} / I_{2}$ couple noticeably [16].

\section{Conclusions}

Lil mediated cells in the presence of water and the ionic liquid $\mathrm{Pyr}_{14} \mathrm{TFSI}$ produce reversible $4 \mathrm{e} / \mathrm{O}_{2}$ ORR and OER at 2.6 V and 3.2-3.5 V respectively during capacity-limiting galvanostatic cycling in operando online electrochemical mass spectrometry (OEMS) experiments. A combination of ex-situ characterization methods confirm that these reactions occur through the formation/decomposition of $\mathrm{LiOH}$. OEMS experiments with $\mathrm{Li}_{2} \mathrm{O}_{2}$ preloaded electrodes show that the electrolyte mixture is also capable of efficiently decomposing $\mathrm{Li}_{2} \mathrm{O}_{2}$ through a $2 \mathrm{e} / \mathrm{O}_{2}$ during OER. The presence of $\mathrm{Pyr}_{14} \mathrm{TFSI}$ increases the $1 / \mathrm{l}_{3}^{-}$redox potential shifting the mechanism of the OER from the irreversible production of $1 \mathrm{O}^{-} / \mathrm{IO}_{3}$ to the evolution of $\mathrm{O}_{2}$. The combination of an $\mathrm{IL}$ and water in aprotic electrolytes is an effective strategy for tailoring the electrolyte properties and reaction mechanisms in redox-mediated $\mathrm{Li}_{-} \mathrm{O}_{2}$ batteries.

\section{Methods}

Materials preparation. Carbon electrodes were prepared by kneading a slurry made from 75 wt\% carbon black (Ensaco P150, Imerys) and 25\% PTFE binder (Aldrich, 60\% water solution) in ethanol until a homogeneous film was obtained. Free-standing discs were cut from this film, annealed at $120^{\circ} \mathrm{C}$ in vacuo for 12 hours and transferred to the glovebox without exposure to air. The areal loading of the carbon electrode is $\sim 1-2 \mathrm{mg} / \mathrm{cm}^{2}$. Tetraethylene glycol dimethyl ether (G4, Aldrich, 99\%) was refluxed with sodium metal under Ar for 3 days prior to fractional distillation in vacuo. The final water content was measured by Karl Fischer titration (Metrohm 899) at $<10$ ppm, and then stored over $4 \AA$ molecular sieves. Lithium bis(trifluoromethyl)sulfonylimide (LiTFSI, 3M FluoradTM, $\mathrm{HQ115}$ ) and Lil (Aldrich, 99.9\%) were dried in vacuo at $160^{\circ} \mathrm{C}$ and $200^{\circ} \mathrm{C}$ respectively for 12 hours before being used to prepare the electrolyte. Pyrrolidinium (1,4)-bis-(trifluoromethanesulfonyl)imide-TFSI ( $\mathrm{Pyr}_{14} \mathrm{TFSI}$, Solvionic 99.9\%; $\mathrm{H}_{2} \mathrm{O} \leq 0,002 \%$ ) was used as purchased. All materials were stored and handled in an $\mathrm{Ar}$ glovebox with $<0.1 \mathrm{ppm} \mathrm{O}_{2}$ and $<0.1 \mathrm{ppm} \mathrm{H}_{2} \mathrm{O}$.

Electrochemical methods. All $\mathrm{Li}_{-} \mathrm{O}_{2}$ cells were assembled inside an Ar-filled glove box on boredthrough stainless-steel Swagelok unions by staking a Li disc (PI-KEM, 99.99\%), 1 piece of pressed borosilicate glass fibre separator (Whatman) wetted with 0.3M LiTFSI / G4 (anolyte), a disk of lithium-ion conducting glass ceramic (Ohara AG01), 1 piece of pressed borosilicate glass fibre separator wetted with $210 \mu \mathrm{l}$ of the active catholyte, and Ensaco P150 cathode. Stainless steel mesh (details) was used as current collector. Electrochemical tests were performed on either a Biologic SP300 or an Ivium Vertex potentiostat/galvanostat. Due to the significant resistance of LICGC disk, the resistance was measured by impedance spectroscopy. Ohm's Law was then applied to obtain the Ohmic overpotential (Supplementary Fig. 12), which was then subtracted in the load curves. A newly designed Online Electrochemical Mass Spectrometry (OEMS) system was developed for this work and it is described in detail in the supplementary information (Supplementary Fig. S1a). The cell 
design consists in a 1" Swagelok union with inlet and outlet tubes (1/16") welded to the top plunger (with $\sim 0.83 \mathrm{~cm}^{3}$ headspace) and capped with self-sealing quick-connects (Beswick Engineering) to isolate the cell from the atmosphere between assembly in the glove box and connection to the OEMS system. Galvanostatic discharge and charge were carried out under $20 \% \mathrm{O}_{2}$, and $0 \% \mathrm{O}_{2}$ in $\mathrm{Ar}$ respectively. A newly designed pressure monitoring cell assembly was also developed for this work and it is also described in detail in the supplementary information (Supplementary Fig. 1b). A pressure transducer was connected to a 1" Swagelok cell and sealed in the glove box. The cell assembly was then pumped down and subsequently filled up with pure $\mathrm{O}_{2}$. The total internal volume of the setup was measured independently for each test using a reference volume and the measured change in pressure was then converted to number of moles of gas consumed using the Ideal gas law.

Characterization methods. Characterization of electrodes after electrochemical tests was performed by first disassembling the cell inside the glove box, rinsing the cathode twice in dry DME, then drying them in vacuo. Powder X-ray diffraction measurements were performed with the electrode placed in an air-tight sample holder in a Panalytical Empyrean diffractometer, in reflection mode with Cu Ka1 radiation ( $\lambda=1.5406 \AA$ ). Ultraviolet spectra were acquired on samples in an air tight quartz cuvette in a LAMBDA TM 25/35, PerkinElmer spectrometer. G4 was used for dilutions, and pristine electrolyte was used as reference. Scanning electron microscopy was obtained in a Tescan MIRA3 microscope $(5 \mathrm{keV} ; 7 \mathrm{pA})$ with samples transported from the glove box sealed in a Kammrath \& Weiss transfer module. Titration experiments were performed following the method previously reported by McCloskey et al. [32]. Cathodes were extracted from cells inside the glove box and placed in a sealed vial unwashed. $2 \mathrm{ml}$ of ultrapure water (Millipore) were injected into the vial using a syringe and then titration of the base was done with a standardized $0.01 \mathrm{M} \mathrm{HCl}$ solution, using phenolphthalein as end-point indicator while vigorously stirring. After acid-base titration $1 \mathrm{ml}$ of $\mathrm{KI}(2 \mathrm{wt} \%), 1 \mathrm{ml}$ of $\mathrm{H}_{2} \mathrm{SO}_{4}(3.5 \mathrm{M})$ and $50 \mathrm{ml}$ of a molybdenum-based catalyst solution were added. The $\mathrm{I}_{2}$ generated is then quickly titrated using $0.01 \mathrm{~N} \mathrm{NaS}_{2} \mathrm{O}_{3}$ solution using a starch indicator. The quantification of electrochemically generated $\mathrm{LiOH}$ during cell discharge is done by subtracting the amount of $\mathrm{LiOH}$ generated by the reaction of $\mathrm{Li}_{2} \mathrm{O}_{2}$ with $\mathrm{H}_{2} \mathrm{O}\left(\mathrm{Li}_{2} \mathrm{O}_{2}+2 \mathrm{H}_{2} \mathrm{O} \rightarrow 2 \mathrm{LiOH}+\mathrm{H}_{2} \mathrm{O}_{2}\right)$. The amount of $\mathrm{LiOH}$ generated from electrochemically generated $\mathrm{Li}_{2} \mathrm{O}_{2}$ during cell discharge is then calculated from the amount of $\mathrm{I}_{2}$ generated from $\mathrm{H}_{2} \mathrm{O}_{2}\left(\mathrm{H}_{2} \mathrm{O}_{2}+2 \mathrm{KI}+\mathrm{H}_{2} \mathrm{SO}_{4} \rightarrow \mathrm{I}_{2}+\mathrm{K}_{2} \mathrm{SO}_{4}+2 \mathrm{H}_{2} \mathrm{O}\right)$, which is measured during the iodometric titration $\left(\mathrm{I}_{2}+2 \mathrm{Na}_{2} \mathrm{~S}_{2} \mathrm{O}_{3} \rightarrow \mathrm{Na}_{2} \mathrm{~S}_{4} \mathrm{O}_{6}+2 \mathrm{Nal}\right)$. It is important to note that the presence of $\mathrm{I}_{3}{ }^{-}$, formed during discharge, acts as false positive in the iodometric titration, increasing the amount of $\mathrm{Li}_{2} \mathrm{O}_{2}$ detected. Since the quantification of electrochemically generated $\mathrm{LiOH}$ is subsequently calculated from the subtraction of the amount of $\mathrm{Li}_{2} \mathrm{O}_{2}$ detected, this has therefore an effect of decreasing the calculated amount of $\mathrm{LiOH}$. The $\mathrm{LiOH} / \mathrm{Li}_{2} \mathrm{O}_{2}$ ratio obtained must be treated therefore as an underestimation of $\mathrm{LiOH}$ content in the discharge product.

\section{Acknowledgements}

This research was enabled by funding support from Innovate UK (132220) and the EPSRC (EP/M009521/1 DJR00640). The authors wish to acknowledge experimental contributions to this work by C. Brackstone for help with titration, Dr Y. Jin with ssNMR, and S. Engelke with cyclic voltammograms.

\section{References}

1 Bose Styczynski, A. \& Hughes, L., Public policy strategies for next-generation vehicle technologies: An overview of leading markets. Environmental Innovation and Societal Transitions 31, 262-272 (2018). 
Meckling, J. \& Nahm, J., The politics of technology bans: Industrial policy competition and green goals for the auto industry. Energy Policy 126, 470-479 (2019). Grey, C.P. \& Tarascon, J.M., Sustainability and in situ monitoring in battery development. Nature Materials 16, 45-56 (2017). Aurbach, D., McCloskey, B.D., Nazar, L.F., \& Bruce, P.G., Advances in understanding mechanisms underpinning lithium-air batteries. Nature Energy 1, 16128 (2016). Girishkumar, G., McCloskey, B., Luntz, A.C., Swanson, S., \& Wilcke, W., Lithium-Air Battery: Promise and Challenges. The Journal of Physical Chemistry Letters 1 (14), 2193-2203 (2010). Kwabi, D.G. et al., Materials challenges in rechargeable lithium-air batteries. MRS Bulletin 39 (5), 443-452 (2014). Mahne, N. et al., Singlet oxygen generation as a major cause for parasitic reactions during cycling of aprotic lithium-oxygen batteries. Nature Energy 2, 17036 (2017). $\mathrm{Liu}, \mathrm{T}$. et al., Understanding LiOH Formation in a $\mathrm{Li}^{-} \mathrm{O}_{2}$ Battery with Lil and $\mathrm{H}_{2} \mathrm{O}$ Additives. ACS Catalysis, 66-77 (2018).

$\mathrm{Liu}, \mathrm{T}$. et al., Cycling $\mathrm{Li}_{-} \mathrm{O}_{2}$ batteries via LiOH formation and decomposition. Science 350 (6260), 530-533 (2015). $\mathrm{Liu}, \mathrm{T}$. et al., Understanding LiOH Chemistry in a Ruthenium Catalyzed $\mathrm{Li}_{-} \mathrm{O}_{2}$ Battery. Angewandte Chemie 129 (50), 16273-16278 (2017).

Liu, T., Kim, G., Carretero-González, J., Castillo-Martínez, E., \& Grey, C.P., Response to Comment on "Cycling $\mathrm{Li}^{-\mathrm{O}_{2}}$ batteries via LiOH formation and decomposition". Science 352 (6286), 667d-667d (2015).

Burke, C.M. et al., Implications of 4 e- Oxygen Reduction via lodide Redox Mediation in $\mathrm{Li}^{-} \mathrm{O}_{2}$ Batteries. ACS Energy Letters 1 (4), 747-756 (2016).

Qiao, Y. et al., Unraveling the Complex Role of lodide Additives in $\mathrm{Li}^{-} \mathrm{O}_{2}$ Batteries. ACS Energy Letters 2 (8), 1869-1878 (2017).

Shen, Y., Zhang, W., Chou, S.-L., \& Dou, S.-X., Comment on "Cycling $\mathrm{LiO}_{2}$ batteries via $\mathrm{LiOH}$ formation and decomposition". Science 352 (6286), 667-667 (2015).

Viswanathan, V. et al., Comment on "Cycling $\mathrm{Li}^{-\mathrm{O}_{2}}$ batteries via $\mathrm{LiOH}$ formation and decomposition". Science 352 (6286), 667-667 (2015).

Bentley, C.L., Bond, A.M., Hollenkamp, A.F., Mahon, P.J., \& Zhang, J., Voltammetric Determination of the lodide/lodine Formal Potential and Triiodide Stability Constant in Conventional and Ionic Liquid Media. The Journal of Physical Chemistry C 119 (39), 2239222403 (2015).

Leverick, G., Tulodziecki, M., Tatara, R., Bardé, F., \& Shao-Horn, Y., Solvent-Dependent Oxidizing Power of Lil Redox Couples for $\mathrm{Li}^{-\mathrm{O}_{2}}$ Batteries. Joule 3 (4), 1106-1126 (2019). Nakanishi, A. et al., Electrolyte Composition in Li/O2 Batteries with Lil Redox Mediators: Solvation Effects on Redox Potentials and Implications for Redox Shuttling. The Journal of Physical Chemistry C 122 (3), 1522-1534 (2018).

Wu, S. et al., A Synergistic System for Lithium-Oxygen Batteries in Humid Atmosphere Integrating a Composite Cathode and a Hydrophobic Ionic Liquid-Based Electrolyte. Advanced Functional Materials 26 (19), 3291-3298 (2016).

Allen, C.J. et al., Oxygen Reduction Reactions in lonic Liquids and the Formulation of a General ORR Mechanism for Li-Air Batteries. The Journal of Physical Chemistry C 116 (39), 20755-20764 (2012).

Elia, G.A. et al., An Advanced Lithium-Air Battery Exploiting an Ionic Liquid-Based Electrolyte. Nano Letters 14 (11), 6572-6577 (2014).

Piana, M. et al., Stability of a Pyrrolidinium-Based Ionic Liquid in $\mathrm{Li}_{-} \mathrm{O}_{2}$ Cells. Journal of The Electrochemical Society 161 (14), A1992-A2001 (2014). 
Shimizu, K. et al., Structural and aggregate analyses of (Li salt + glyme) mixtures: the complex nature of solvate ionic liquids. Physical Chemistry Chemical Physics 17 (34), 2232122335 (2015). Elia, G.A., Bernhard, R., \& Hassoun, J., A lithium-ion oxygen battery using a polyethylene glyme electrolyte mixed with an ionic liquid. RSC Advances 5 (27), 21360-21365 (2015). Amanchukwu, C.V. et al., One-Electron Mechanism in a Gel-Polymer Electrolyte $\mathrm{Li}_{2} \mathrm{O}_{2}$ Battery. Chemistry of Materials 28 (19), 7167-7177 (2016).

Mozhzhukhina, N., Tesio, A.Y., De Leo, L.P.M., \& Calvo, E.J., In Situ Infrared Spectroscopy Study of PYR ${ }_{14}$ TFSI lonic Liquid Stability for Li- $\mathrm{O}_{2}$ Battery. Journal of The Electrochemical Society 164 (2), A518-A523 (2017). Monaco, S., Soavi, F., \& Mastragostino, M., Role of Oxygen Mass Transport in Rechargeable Li/O2 Batteries Operating with lonic Liquids. The Journal of Physical Chemistry Letters 4 (9), 1379-1382 (2013).

Meini, S., Solchenbach, S., Piana, M., \& Gasteiger, H.A., The Role of Electrolyte Solvent Stability and Electrolyte Impurities in the Electrooxidation of $\mathrm{Li}_{2} \mathrm{O}_{2}$ in $\mathrm{Li}^{-} \mathrm{O}_{2}$ Batteries. Journal of The Electrochemical Society 161 (9), A1306-A1314 (2014). Haskins, J.B., Yildirim, H., Bauschlicher, C.W., \& Lawson, J.W., Decomposition of Ionic Liquids at Lithium Interfaces. 2. Gas Phase Computations. The Journal of Physical Chemistry C 121 (51), 28235-28248 (2017).

Yildirim, H., Haskins, J.B., Bauschlicher, C.W., \& Lawson, J.W., Decomposition of Ionic Liquids at Lithium Interfaces. 1. Ab Initio Molecular Dynamics Simulations. The Journal of Physical Chemistry C 121 (51), 28214-28234 (2017).

Mohzhukhina, N., Tesio, A.Y., Pozo, M.d., \& Calvo, E.J., Communication-Lithium Ion Concentration Effect in PYR ${ }_{14} \mathrm{TFSI}$ Ionic Liquid for $\mathrm{Li}^{-\mathrm{O}_{2}}$ Battery Cathodes. Journal of The Electrochemical Society 164 (8), H5277-H5279 (2017).

McCloskey, B.D. et al., Combining Accurate $\mathrm{O}_{2}$ and $\mathrm{Li}_{2} \mathrm{O}_{2}$ Assays to Separate Discharge and Charge Stability Limitations in Nonaqueous $\mathrm{Li}^{-} \mathrm{O}_{2}$ Batteries. The Journal of Physical Chemistry Letters 4 (17), 2989-2993 (2013).

Gallant, B.M. et al., Influence of $\mathrm{Li}_{2} \mathrm{O}_{2}$ morphology on oxygen reduction and evolution kinetics in $\mathrm{Li}_{-} \mathrm{O}_{2}$ batteries. Energy \& Environmental Science 6 (8), 2518-2528 (2013). Lu, Y.-C. \& Shao-Horn, Y., Probing the Reaction Kinetics of the Charge Reactions of Nonaqueous $\mathrm{Li}_{-} \mathrm{O}_{2}$ Batteries. The Journal of Physical Chemistry Letters 4 (1), 93-99 (2013). McCloskey, B.D., Bethune, D.S., Shelby, R.M., Girishkumar, G., \& Luntz, A.C., Solvent's Critical Role in Nonaqueous Lithium-Oxygen Battery Electrochemistry. The Journal of Physical Chemistry Letters 2 (10), 1161-1166 (2011).

Tulodziecki, M. et al., The role of iodide in the formation of lithium hydroxide in lithiumoxygen batteries. Energy \& Environmental Science 10 (8), 1828-1842 (2017). Torres, A.E. \& Balbuena, P.B., Exploring the LiOH Formation Reaction Mechanism in LithiumAir Batteries. Chemistry of Materials 30 (3), 708-717 (2018).

$\mathrm{Liu}, \mathrm{T}$. et al., Response to Comment on Cycling Li-O2 batteries via LiOH formation and decomposition". Science 352 (6286), 667b-667b (2015). 
Towards reversible and moisture tolerant aprotic lithium-... (600.53 KiB) view on ChemRxiv • download file 


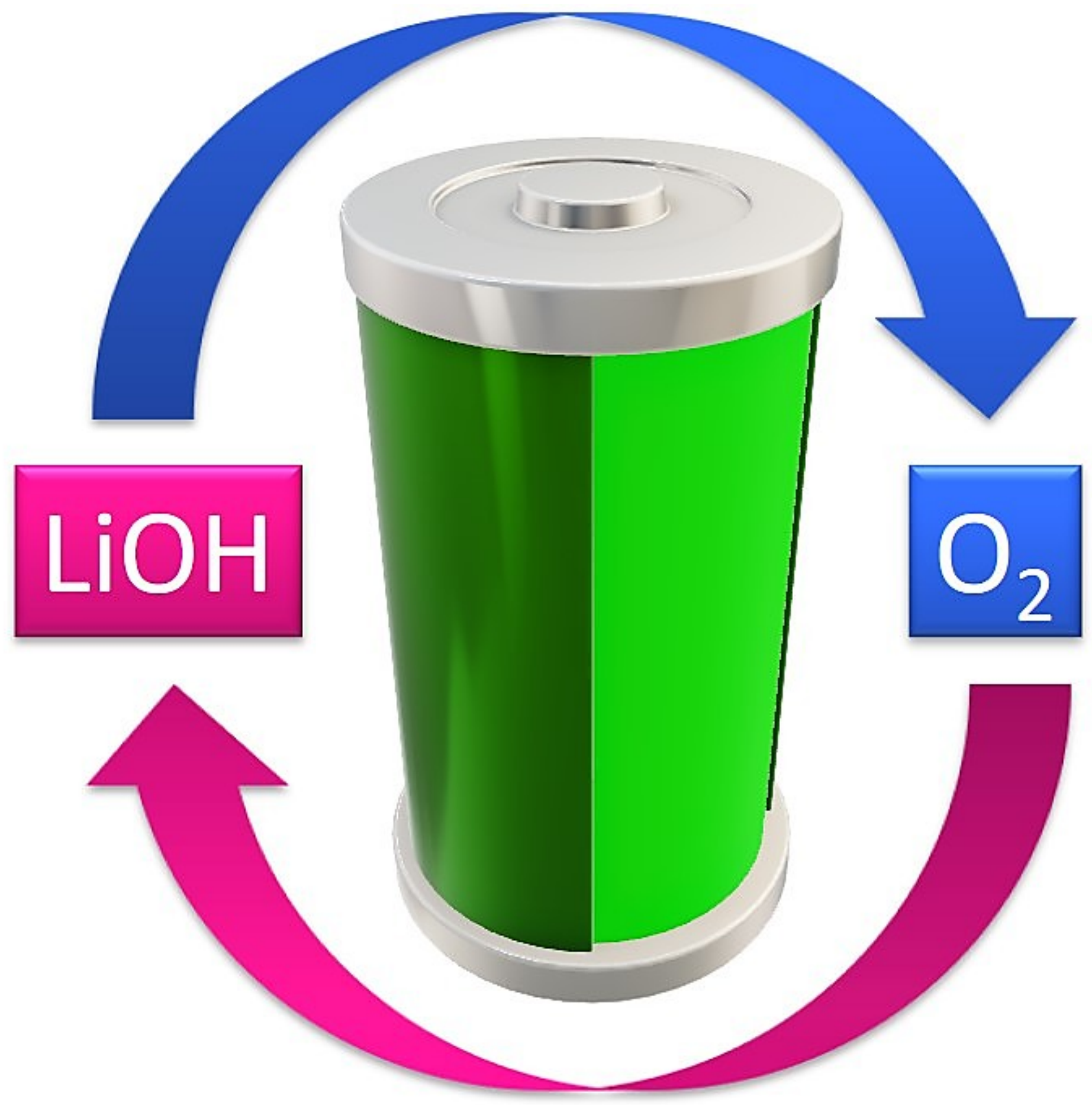




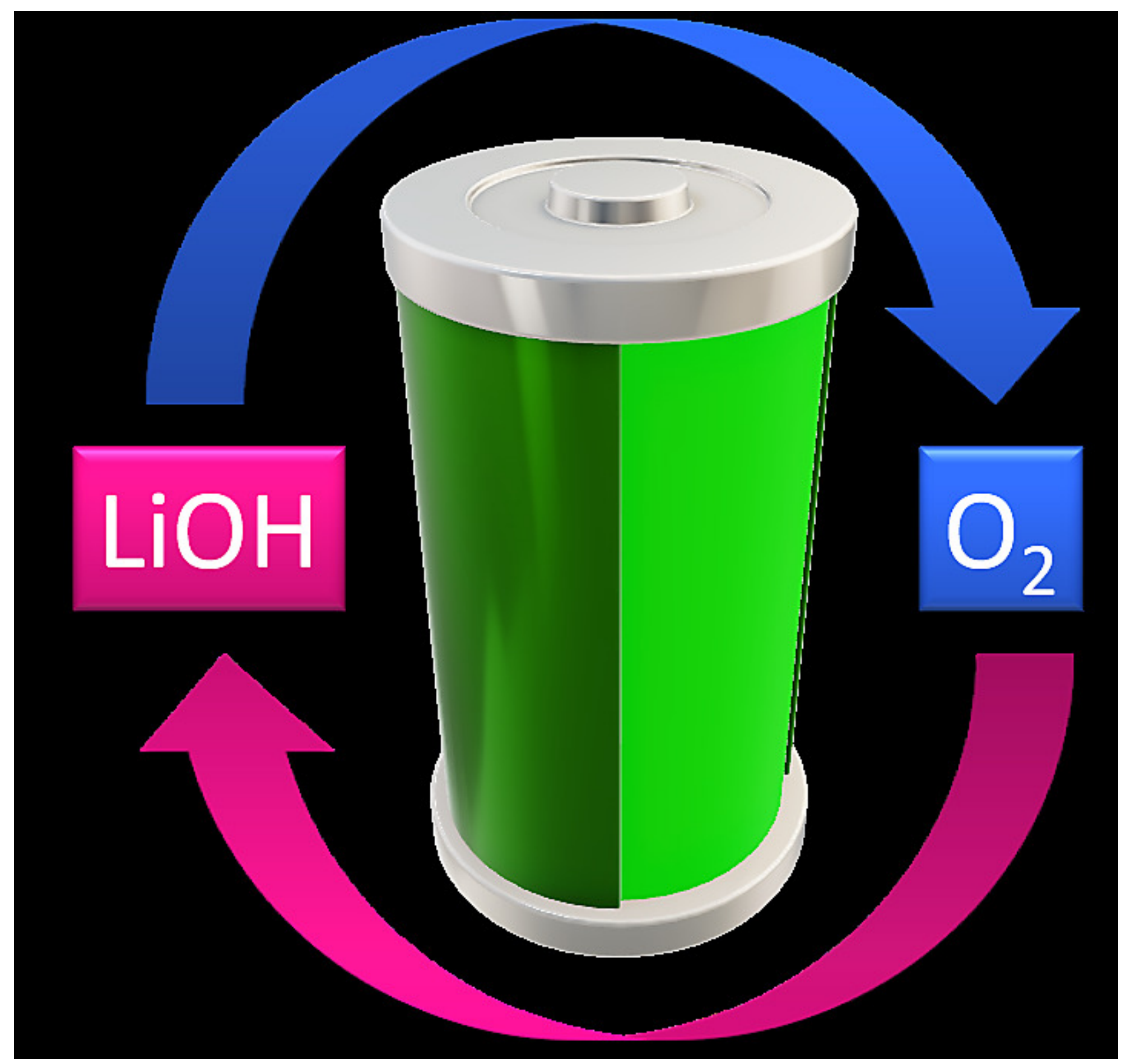

TOC.png (200.33 KiB)

view on ChemRxiv - download file 


\section{Supplementary Information}

\section{Towards reversible and moisture tolerant aprotic lithium-air batteries}

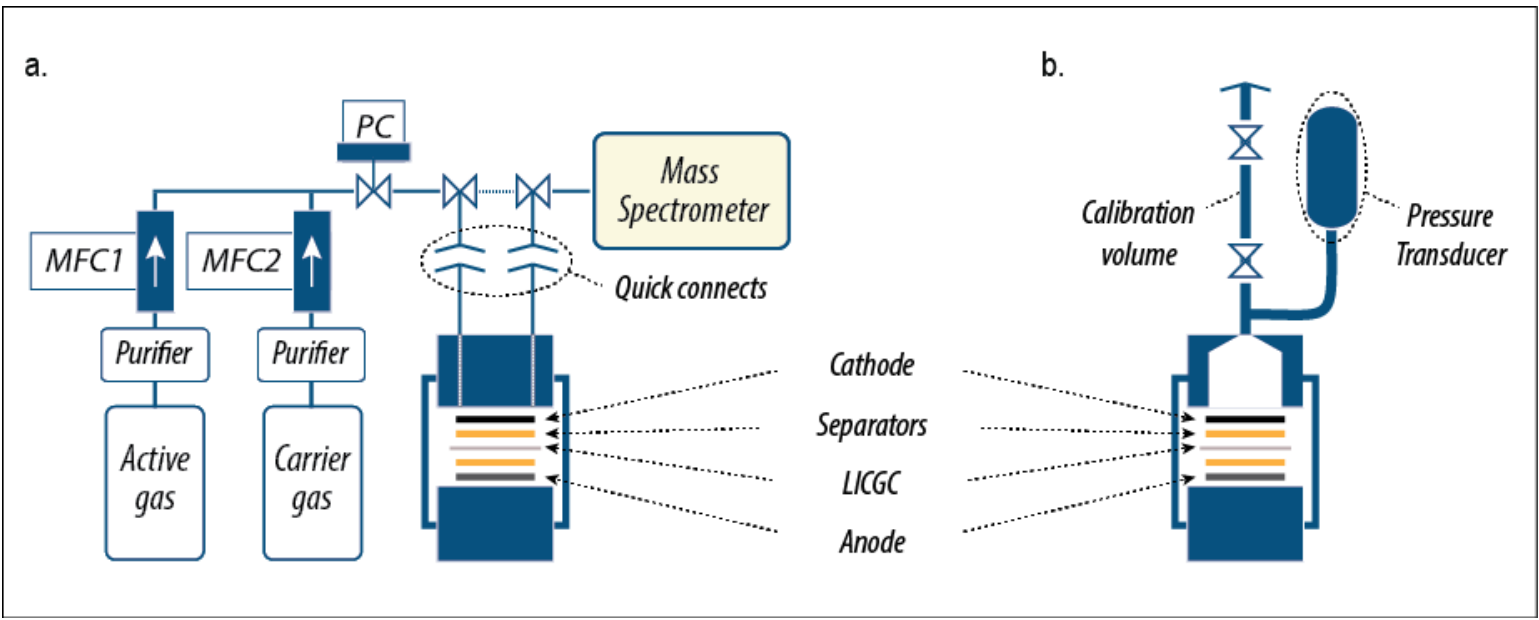

Supplementary Figure 1| Schematics of the operando gas analysis systems used in this work. a, online electrochemical mass spectrometry (OEMS) and $b$, operando pressure monitoring. Two bespoke operando gas analysis techniques were developed in the course of this work. The OEMS system consists of a stainless-steel tube carrying gas through the electrochemical cell (described in main text) to a mass spectrometer. Mixtures of two gases can be selected from 0 to $100 \%$, up to a maximum flow rate of $1120 \mu \mathrm{ln} / \mathrm{s}$, via two mass flow controllers (Bronkhorst), at any given time. For this work argon (BOC N6.0) was used as carrier gas and $\mathrm{O}_{2}$ (BOC N6.0) as active gas, both are connected to purifiers (Bronkhorst) before flow control. A pressure controller (Bronkhorst) was fitted ahead of entering the electrochemical cell for stability reasons. Two PEEK tube sections connect the electrochemical cell to the gas line through self-sealing quick-connects (Beswick Engineering) so the system is never exposed to air. The gas line is connected to a quadrupole mass spectrometer (Pfeiffer) through a heated capillary $\left(120^{\circ} \mathrm{C}\right)$ to prevent condensation. A potentiostat (Ivium) controls the electrochemical operations. The pressure monitoring system consist in an all-metal assembly, with a small internal volume $(\sim 10 \mathrm{ml})$, connecting a pressure transducer (Omega) to a Swagelok-type electrochemical cell. The gas inlet incorporates a small section of tube between two valves, creating an enclosed volume of known value that is used for calibration. Gases are evacuated/introduced through a quick-connect (Swagelok) 

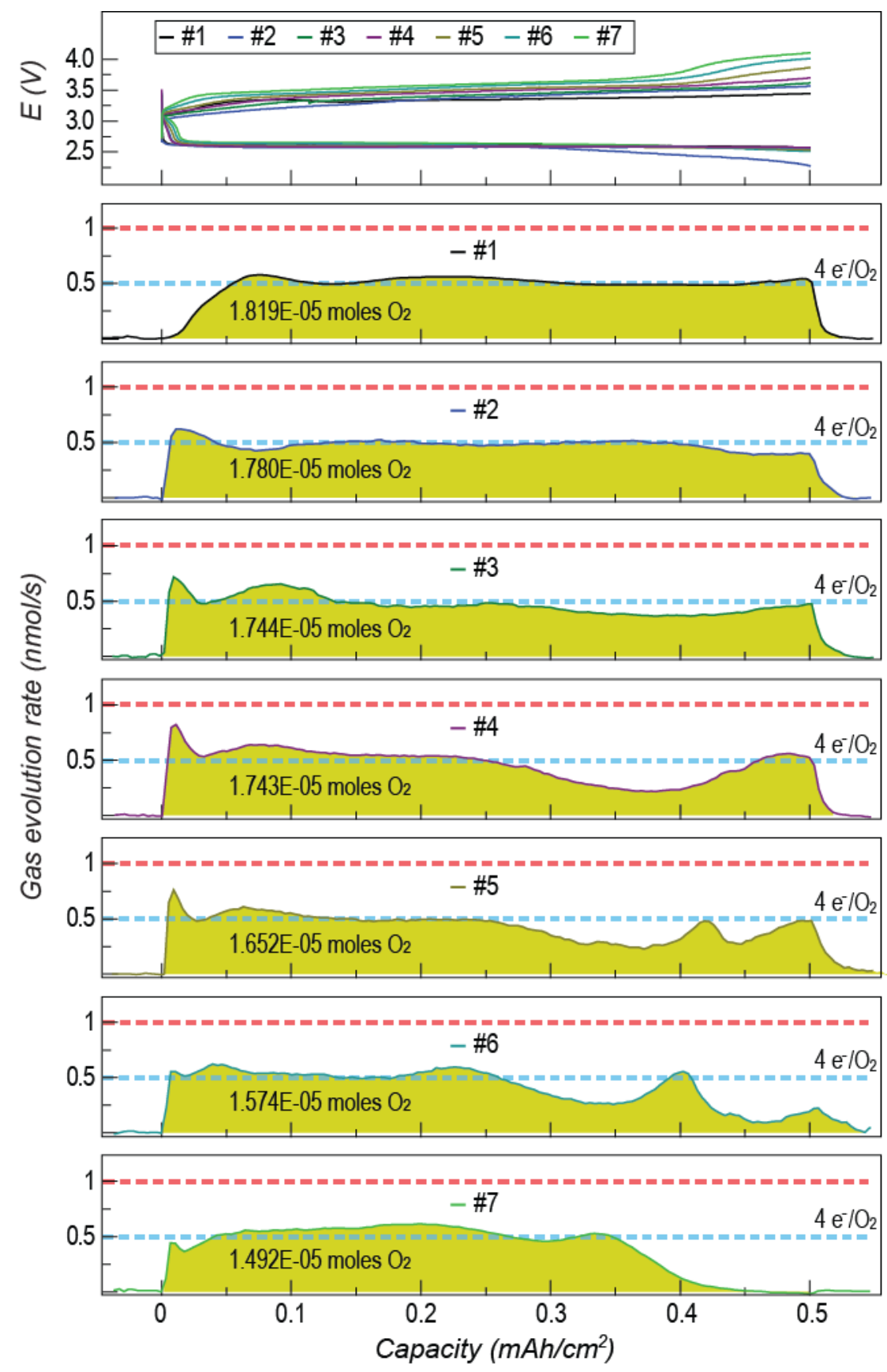

Supplementary Figure 2| Galvanostatic profiles (top) with online mass spectrometry analysis of oxygen $(\mathrm{m} / \mathrm{z}=32)$ for the first 7 cycles at a current of $50 \mu \mathrm{A} / \mathrm{cm}^{2}$ in an electrolyte comprising $0.9 \mathrm{M}$ $\mathrm{Pyr}_{14}{ }_{\mathrm{TFSI}}, 0.7 \mathrm{M}$ LiTFSI, $50 \mathrm{mM} \mathrm{Lil}$, and $5000 \mathrm{ppm} \mathrm{H}_{2} \mathrm{O}$ in of tetraethylene glycol dimethyl ether (G4). 

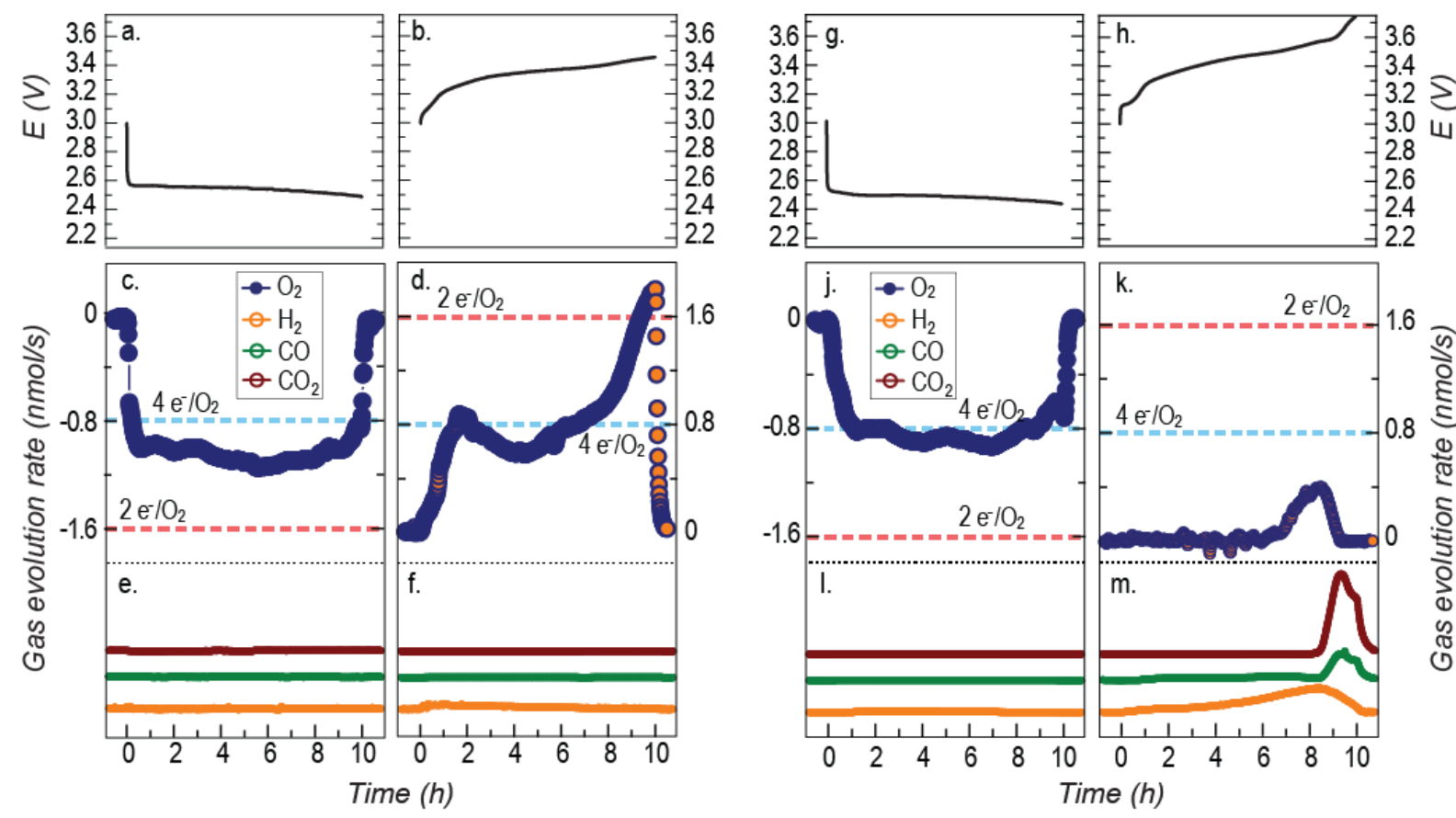

Supplementary Figure $\mathbf{3} \mid \mathbf{a}, \mathbf{c}, \mathbf{e}, \mathbf{g}$, Galvanostatic profiles and $\mathbf{b}, \mathbf{d}, \mathbf{f}, \mathbf{h}$, online mass spectrometry analysis of oxygen $(\mathrm{m} / \mathrm{z}=32)$, hydrogen $(\mathrm{m} / \mathrm{z}=2)$, carbon monoxide $(\mathrm{m} / \mathrm{z}=28)$ and carbon dioxide $(\mathrm{m} / \mathrm{z}=44)$ evolution of cells cycled at a current of $70 \mu \mathrm{A} / \mathrm{cm}^{2}$ in an electrolyte comprising $0.9 \mathrm{M}$ Pyr $_{14}$ TFSI, $0.7 \mathrm{M}$ LiTFSI, $50 \mathrm{mM}$ Lil, and 5000 ppm H $\mathrm{H}_{2} \mathrm{O}$ in G4 (left) and $0.7 \mathrm{M} \mathrm{LiTFSI}, 50 \mathrm{mM}$ Lil, and 5000 ppm $\mathrm{H}_{2} \mathrm{O}$ in $\mathrm{G} 4$ (right). An oxygen consumption corresponding to a stoichiometry of $<4 \mathrm{e} / \mathrm{O}_{2}$ is observed in cells containing $\mathrm{Pyr}_{14} \mathrm{TFSI}$ at this rate and correlates with two distinctive processes during the OER, one of $\sim 4 \mathrm{e}^{-} / \mathrm{O}_{2}$ between $3.15 \mathrm{~V}$ and $3.4 \mathrm{~V}(\sim 70 \%$ of capacity) and a second at the end of charge of $\sim 2 \mathrm{e}^{-} / \mathrm{O}_{2}$ above $3.4 \mathrm{~V}$. Cells without $\mathrm{Pyr}_{14} \mathrm{TFSI}$ (right) show a $4 \mathrm{e}^{-} / \mathrm{O}_{2}$ during discharge but no oxygen evolution below $3.5 \mathrm{~V}$ during charge. A small $\mathrm{O}_{2}$ evolution is observed above $3.5 \mathrm{~V}$ followed up by the evolution of $\mathrm{CO}$ and $\mathrm{CO}_{2}$, indicating electrolyte degradation at these potentials. 

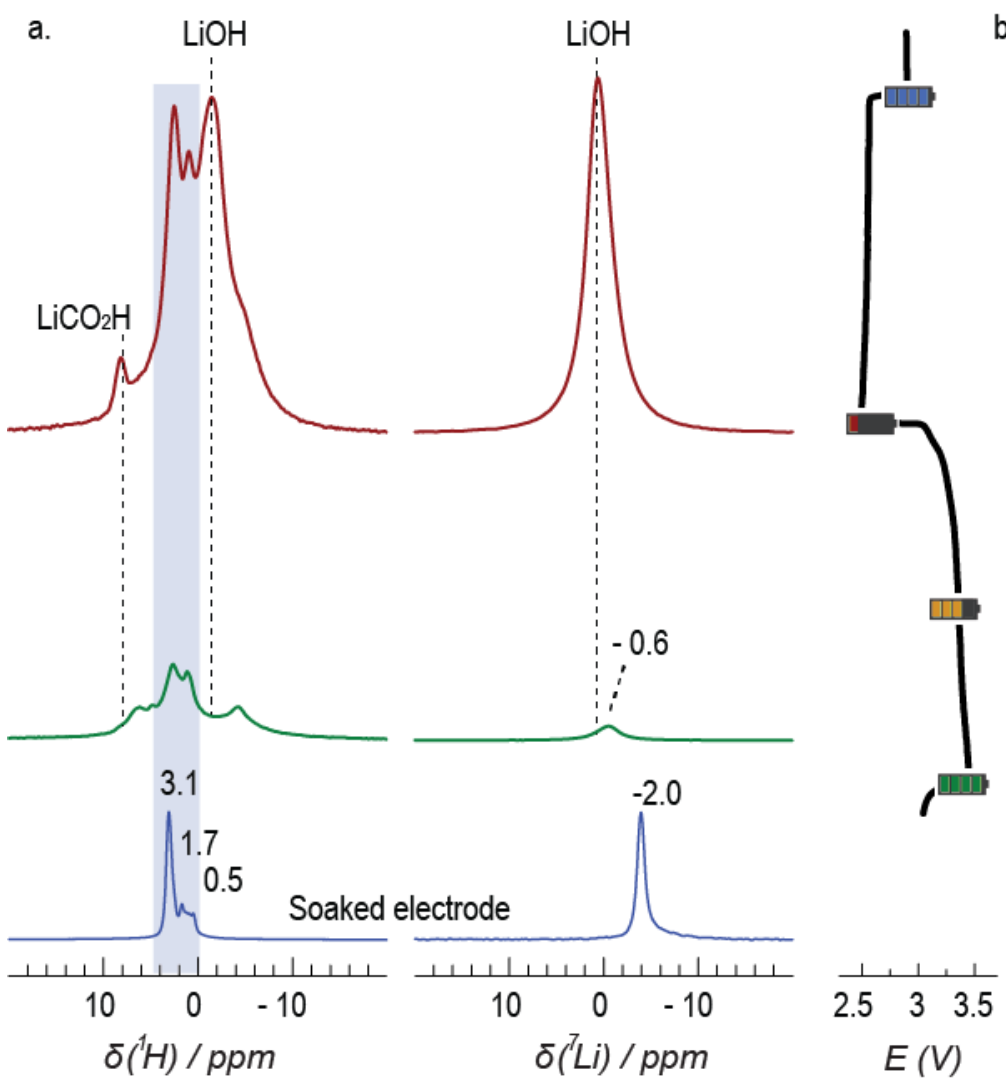

b.
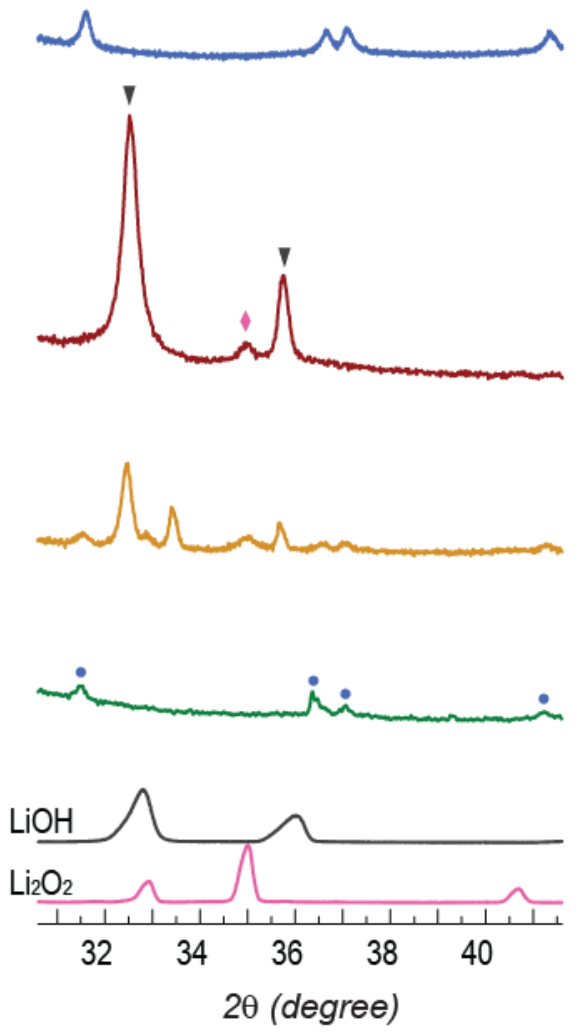

Supplementary Figure $4 \mid \mathbf{a},{ }^{1} \mathrm{H}$ and ${ }^{7} \mathrm{Li}$ solid state NMR (ssNMR); b, X-ray diffractograms, and of electrodes at different stages of capacity-limited $\left(0.7 \mathrm{~mA} / \mathrm{cm}^{2}\right)$ cycling with $0.9 \mathrm{M} \mathrm{Pyr}{ }_{14} \mathrm{TFSI}, 0.7 \mathrm{M}$ LiTFSI, $50 \mathrm{mM}$ Lil, and $5000 \mathrm{ppm} \mathrm{H}_{2} \mathrm{O}$ in $\mathrm{G} 4$ at $70 \mu \mathrm{A} / \mathrm{cm}^{2}$ (pristine - blue; discharged - red; half charged - amber; fully charged - green); c, SEM images of electrodes at end of discharge (different magnifications). ssNMR spectra were acquired on either a 16.4 T Bruker Avance III or an $11.7 \mathrm{~T}$ Bruker Avance III HD spectrometer using $1.3 \mathrm{~mm} \mathrm{HX} \mathrm{(16.4} \mathrm{and} \mathrm{11.7} \mathrm{T)} \mathrm{and} \mathrm{2.5mm} \mathrm{HX} \mathrm{(11.7} \mathrm{T)} \mathrm{probes.}$ ssNMR shows intense ${ }^{7} \mathrm{Li}$ and ${ }^{1} \mathrm{H}$ signals centred at $0.7 \mathrm{ppm}$ and $-1.5 \mathrm{ppm}$, respectively, indicating the predominant formation of $\mathrm{LiOH}$ as discharge product $[8-10,26]$ (a - red trace). Traces of lithium formate can also be observed in the $1 \mathrm{H}$ spectrum at $9 \mathrm{ppm}$, and were previously reported in the discharge product of cells containing Lil and water in G4, associated to the electrochemical formation of $\mathrm{Li}_{2} \mathrm{O}_{2}$ [9]. After charge an almost complete removal of all lithium-based discharge products is observed (b - green trace). A broad signal is also observed in the ${ }^{1} \mathrm{H}$ spectrum of discharged electrodes, with maxima at $0.5,1.7$, and $3.1 \mathrm{ppm}$, which decreases noticeably in intensity in the charged electrodes. Analysis of unwashed electrodes soaked in electrolyte suggests that these signals originate from electrolyte trapped in the discharge product, which is not completely removed on washing the electrode sample with acetonitrile prior to analysis. A broad ${ }^{1} \mathrm{H}$ resonance at $-4 \mathrm{ppm}$ is assigned to protons in the electrode [27]. The reference NMR spectrum of a pristine electrode soaked in the electrolyte (blue) reveals ${ }^{1} \mathrm{H}$ NMR signals that can be assigned to the solvent in a. XRD patterns of the discharged electrode ( $b$ - red trace) is also dominated by patterns corresponding to crystalline $\mathrm{LiOH}$, however weak reflections from the by-product $\mathrm{Li}_{2} \mathrm{O}_{2}$ can also be observed. At half charge ( $\mathbf{b}$ - amber trace), the reflections associated to $\mathrm{LiOH}$ appear reduced with respect to the fully discharged cell whereas the weak reflection associated to $\mathrm{Li}_{2} \mathrm{O}_{2}$ remains at similar intensity. All reflections associated to both discharge products are absent in the diffractogram corresponding to the fully charged electrodes (b-green trace). Scanning electron microscopy (SEM) images of the discharged electrode show mainly dispersed collections of thin-sheets, consistent with primary building blocks of typical "flowerlike" LiOH crystals [24]. These small crystalline structures, of up to 1 $\mu \mathrm{m}$ in size, are indicative of an electrolyte with limited solvating properties, as expected for highly viscous mixtures $[23,25]$. 


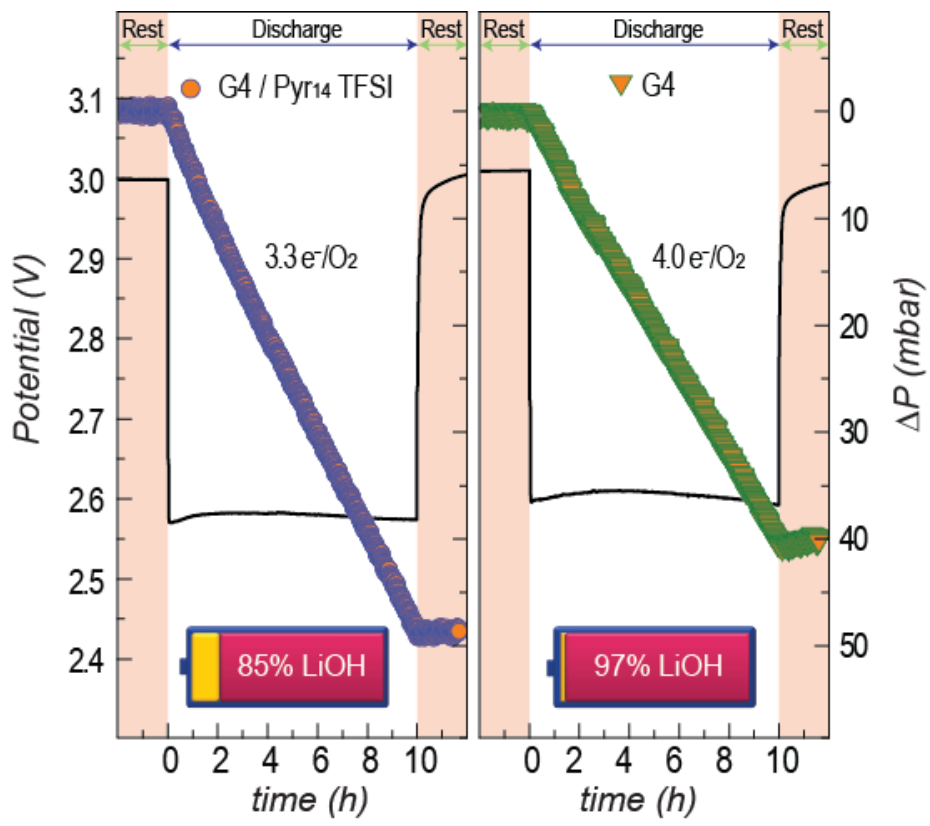

Supplementary Figure 5| Pressure monitoring and titration of cells containing a, $\mathrm{Pyr}_{14} \mathrm{TFSI} / \mathrm{G} 4$, and b, G4 discharged at $70 \mu \mathrm{A} / \mathrm{cm}^{2}$. 


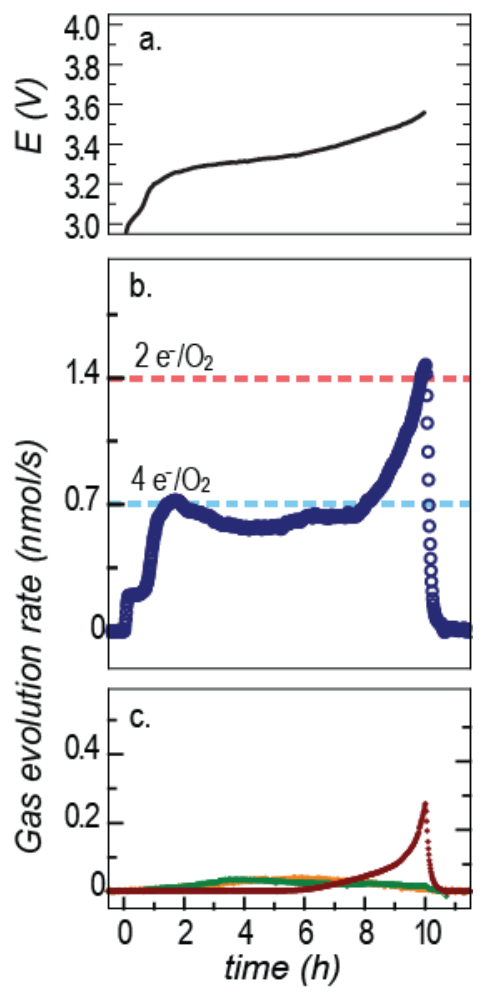

Supplementary Figure $6 \mid$ a, Galvanostatic profile during charge, and online mass spectrometry analysis of $\mathbf{b}$, oxygen $(\mathrm{m} / \mathrm{z}=32)$ and $\mathbf{c}$, hydrogen $(\mathrm{m} / \mathrm{z}=2)$, carbon monoxide $(\mathrm{m} / \mathrm{z}=28)$ and carbon dioxide $(\mathrm{m} / \mathrm{z}=44)$ evolution of a $\mathrm{LiOH}$ (electrochemically) preloaded electrode in an electrolyte comprising $0.9 \mathrm{M} \mathrm{Pyr}_{14} \mathrm{TFSI}, 0.7 \mathrm{M} \mathrm{LiTFSI}, 50 \mathrm{mM}$ Lil, and 5000 ppm $\mathrm{H}_{2} \mathrm{O}$ in $\mathrm{G} 4$ cycled at a current of $70 \mu \mathrm{A} / \mathrm{cm}^{2}$. Three distinctive processes during the OER can be observed: a first small plateau at 3$3.05 \mathrm{~V}(\sim 7.5 \%$ of capacity) showing a small oxygen evolution can be correlated with oxidation of species on the surface of $\mathrm{LiOH}$ crystals that may have formed during washing/drying of the electrode; a second OER region between $3.2 \mathrm{~V}$ and $3.4 \mathrm{~V}$ shows a $4 \mathrm{e} / \mathrm{O}_{2}$ evolution $(\sim 73 \%$ of capacity); a third region above $3.4 \mathrm{~V}$ shows an increase in $\mathrm{O}_{2}$ evolution accompanied by $\mathrm{CO}_{2}$ evolution, indicating parasitic reactions. 


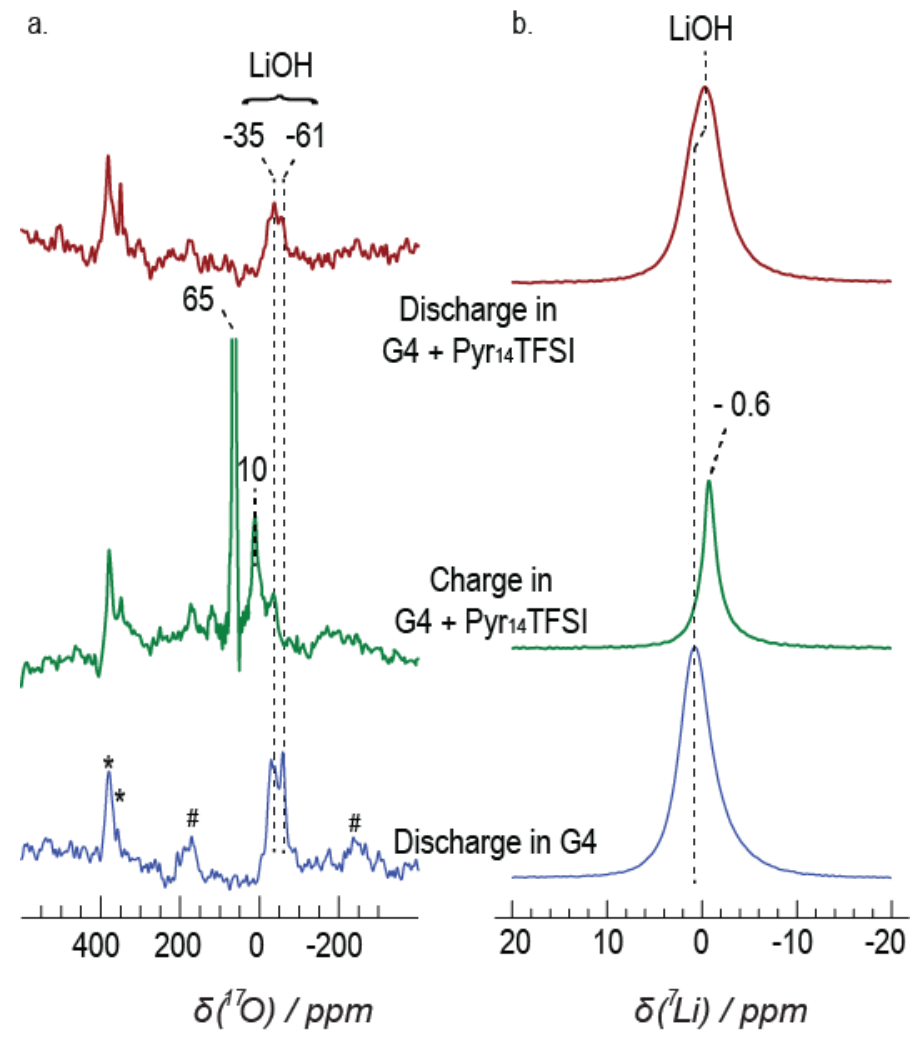

Supplementary Figure $7 \mid \mathbf{a},{ }^{17} \mathrm{O}$ and $\mathbf{b},{ }^{7} \mathrm{Li}$ sSNMR spectra of the discharged (red trace) and charged (green trace) electrodes cycled at a current of $50 \mu \mathrm{A} / \mathrm{cm}^{2}$ in a catholyte comprising $0.9 \mathrm{M} \mathrm{Pyr}{ }_{14} \mathrm{TFSI}$,

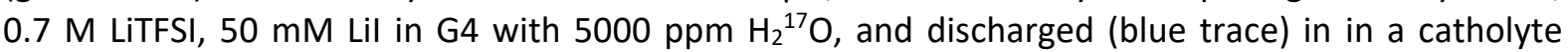

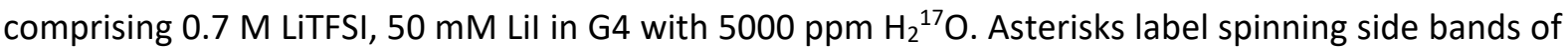
the $\mathrm{ZrO}_{2}$ rotor background signal. Hashtags denotes the spinning sidebands. The data was acquired on a $16.4 \mathrm{~T}$ Bruker Avancelll $700 \mathrm{MHz}$ spectrometer with a $3.2 \mathrm{~mm}$ triple resonance probe using a Hahn echo sequence with an RF amplitude $55 \mathrm{kHz}$, at a MAS frequency of $20 \mathrm{kHz}$ adding 29871 to 60000 transient scans with a relaxation delay of $20 \mathrm{~s}$ for ${ }^{7} \mathrm{Li} .{ }^{17} \mathrm{O}$ and ${ }^{7} \mathrm{Li}$ were externally referenced to $\mathrm{D}_{2} \mathrm{O}$ at $0 \mathrm{ppm}$ and LiF at $-1 \mathrm{ppm}$, respectively. 


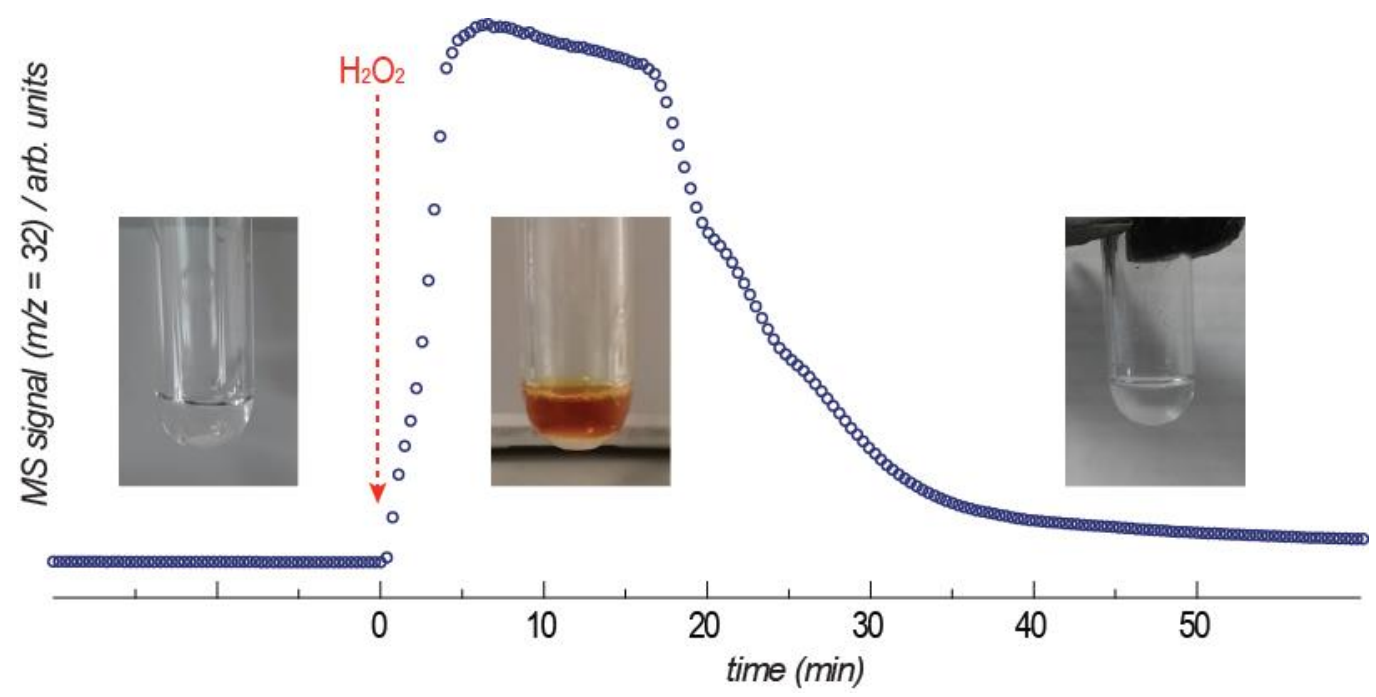

Supplementary Figure 8| Online mass spectrometry chemical test of the reaction of $\mathrm{H}_{2} \mathrm{O}_{2}$ and $\mathrm{I}^{-}$with $10.5 \mathrm{mg}$ of LiOH in $0.5 \mathrm{ml}$ of electrolyte containing $0.9 \mathrm{M} \mathrm{Pyr}_{14} \mathrm{TFSI}, 0.7 \mathrm{M} \mathrm{LiTFSI}, 50 \mathrm{mM}$ Lil, 5000 ppm $\mathrm{H}_{2} \mathrm{O}$ in $\mathrm{G} 4$. At $\mathrm{t}=0,0.2 \mathrm{ml}$ of $\mathrm{H}_{2} \mathrm{O}_{2}$ (30\% wt) is injected. Images of the test tube before, during, and after reaction completion are added for visual reference.

It has been recently proposed that the electrochemical formation of $\mathrm{LiOH}$ in $\mathrm{I}^{-} / \mathrm{I}_{3}^{-}$mediated cells occurs through a synergistic effect, where at $\mathrm{H}_{2} \mathrm{O}: \mathrm{I}^{-}$ratios between 0.5 and 1.5 both $\mathrm{H}_{2} \mathrm{O}$ and $\mathrm{I}^{-}$ coordinate with $\mathrm{Li}^{+}$in their first solvation shells with various glyme solvents [8]. The high proton affinity of $\mathrm{I}^{-}$, higher than TFSI' but lower than $\mathrm{OH}^{-}$based on Pearson's Hard Soft Acid Base (HSAB) Theory, weakens the $\mathrm{O}-\mathrm{H}$ bond of a significant portion of water molecules rendering $\mathrm{H}^{+}$available for the formation of $\mathrm{LiOH}$ (reaction 1).

$\mathrm{O}_{2}+2 \mathrm{H}^{+}+2 \mathrm{e}^{-} \leftrightarrows \mathrm{H}_{2} \mathrm{O}_{2}$

Whereas at higher $\mathrm{H}_{2} \mathrm{O}: \mathrm{I}^{-}$ratios a water clustering effect significantly reduce the average $\mathrm{I}-\mathrm{H}$ interaction attenuating this synergistic action. In this scenario the ORR mechanism proceeds through an iodide catalytic effect in which the electrochemically formed $\mathrm{O}_{2}^{-}$chemically reacts with $\mathrm{H}_{2} \mathrm{O}$ to form $\mathrm{H}_{2} \mathrm{O}_{2}$ (reaction 1), which subsequently oxidizes $\mathrm{I}^{-}$to form $\mathrm{I}_{3}{ }^{-}$and $\mathrm{LiOH}$ (reaction 2 ).

$\mathrm{H}_{2} \mathrm{O}_{2}+3 \mathrm{I}^{-} \leftrightarrows \mathrm{I}_{3}{ }^{-}+2 \mathrm{OH}^{-}$

$\mathrm{I}^{-}$is regenerated via a chemical reaction in which $\mathrm{O}_{2}$ is evolved (reaction 3) making the overall mechanism formally a $4 \mathrm{e} / \mathrm{O}_{2}$ process following the ensuing reaction pathway:

$\mathrm{H}_{2} \mathrm{O}_{2}+\mathrm{I}_{3}^{-}+2 \mathrm{OH}^{-} \leftrightarrows 3 \mathrm{I}^{-}+2 \mathrm{H}_{2} \mathrm{O}+\mathrm{O}_{2}$

To test whether the ORR in cells containing $\mathrm{P}_{14} \mathrm{TFSI}$ follows this mechanism the gas evolution after injecting $\mathrm{H}_{2} \mathrm{O}_{2}$ to a tube containing $\mathrm{LiOH}$ in an aliquot of the electrolyte was tested in an online mass spectrometry chemical test (Fig. 7). Upon injection of $\mathrm{H}_{2} \mathrm{O}_{2}$, the initially transparent electrolyte turned dark red, indicating the formation of $\mathrm{I}_{3}^{-}$as per reaction 2 . Almost immediately bubbles started forming from the $\mathrm{LiOH}$ precipitate and $\mathrm{O}_{2}$ was detected by the mass spectrometer. After a time the solution cleared again and the bubbling stopped, indicating that the formed $\mathrm{I}_{3}{ }^{-}$was being reduced again to $\mathrm{I}^{-}$by the oxidation of $\mathrm{OH}^{-}$, in agreement with reaction 3 . 

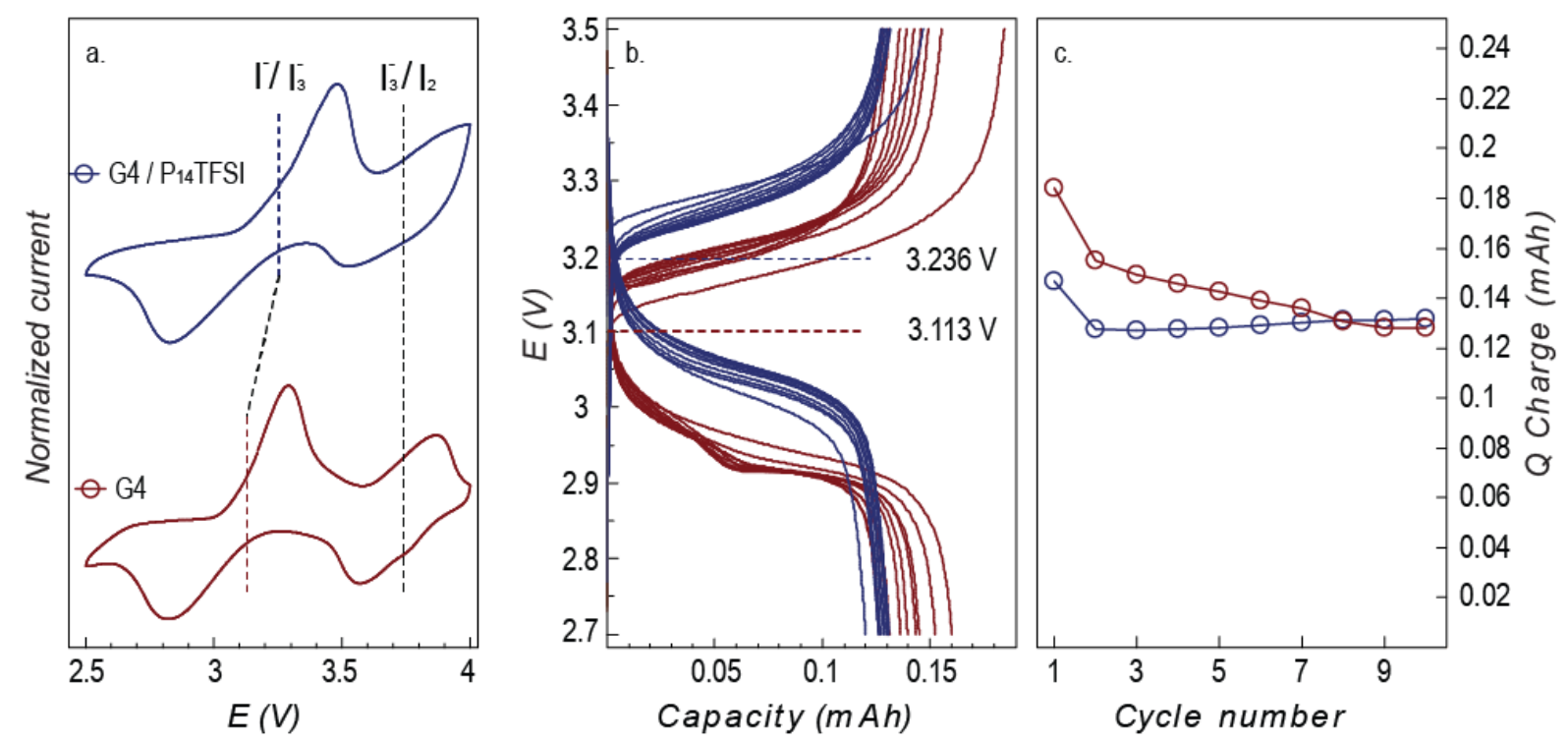

Supplementary Figure $9 \mid$ a, Cyclic voltammograms of cells with catholytes containing $0.7 \mathrm{M}$ LiTFSI, $50 \mathrm{mM}$ Lil, $5000 \mathrm{ppm} \mathrm{H} \mathrm{H}_{2} \mathrm{O}$ in G4 (red trace) and with $0.9 \mathrm{M} \mathrm{Pyr}_{14} \mathrm{TFSI}$ (blue trace) collected at $1 \mathrm{mV} / \mathrm{s}$; b, First 10 galvanostatic discharge/charge cycles) of cells of the same composition; c, charge capacity registered during galvanostatic cycling shown in $\mathrm{b}$. Cells used a LICGC to isolate the cathode from the Li metal anode. 0.3 M LiTFSI in G4 was used as anolyte. All cells were cycled under argon at 50 $\mu \mathrm{A} / \mathrm{cm}^{2}$.

Typically, the reduction and oxidation potentials for reactions are defined by a voltammetric method rather than galvanostatic method. If using a galvanostatic (step) method, as shown in the main text, the process must be a truly reversible reaction whereby the Tafel slopes ares extrapolated to intersection. The cyclic voltammograms (Supplementary Fig. 9a) show good agreement with the galvanostatic cycling results shown in Fig. 4c, even though the potential crossover in observed in figure $4 \mathrm{c}$ are likely reactant species diffusion/concentration dependent values. The potential crossovers and the overall capacity show negligible change over several cycles (Supplementary Fig. 9c). 

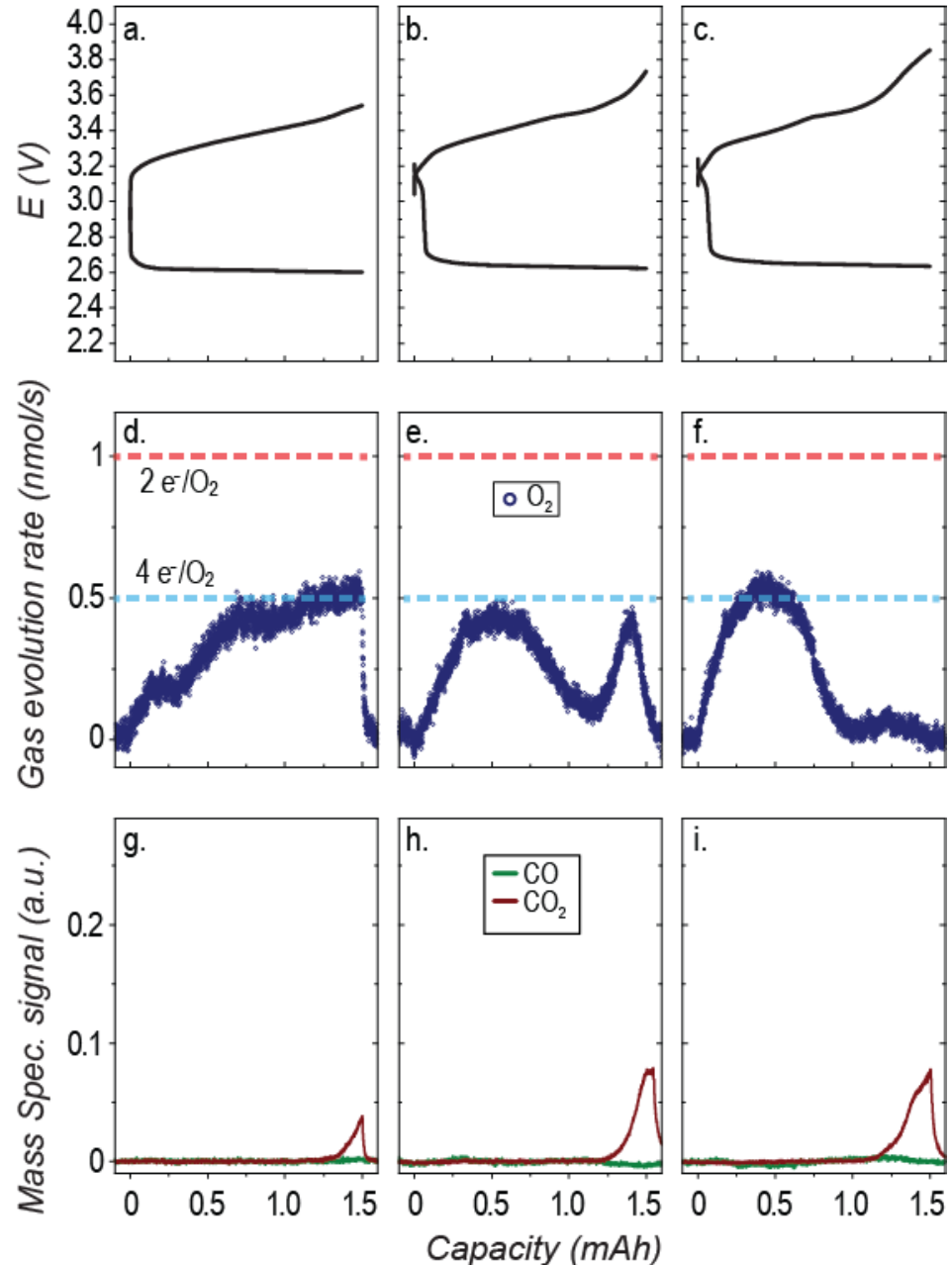

Supplementary Figure 10 a-c, Galvanostatic profiles with online mass spectrometry analysis of d-f, oxygen $(\mathrm{m} / \mathrm{z}=32)$ and $\mathbf{g}-\mathbf{f}$, carbon monoxide and carbon dioxide $(\mathrm{m} / \mathrm{z}=28)$ evolution of cells with an

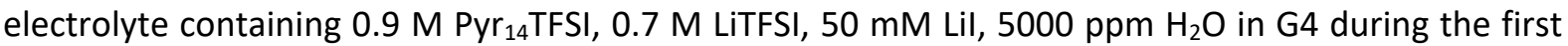
three charges. Cells were assembled in an ECC-DEMS cell (EL-CELL) without LICGC protecting the anode and cycled to $70 \mu \mathrm{A} / \mathrm{cm}^{2}$ under $20 \% \mathrm{O}_{2}$ in $\mathrm{Ar}$ and $0 \% \mathrm{O}_{2}$ in Ar during discharge and charge respectively. 

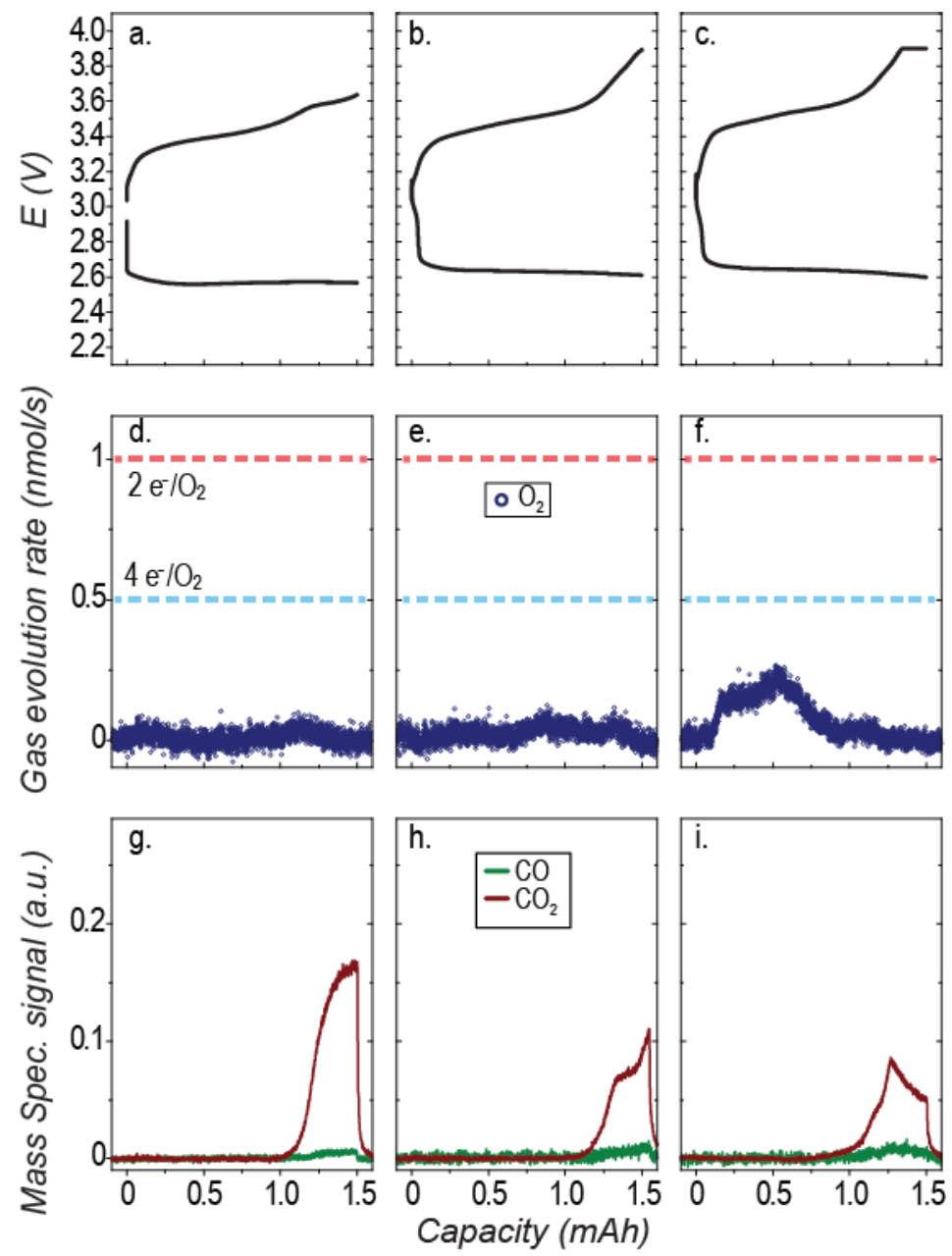

Supplementary Figure 11| a-c, Galvanostatic profiles with online mass spectrometry analysis of $\mathbf{d}-\mathbf{f}$, oxygen $(\mathrm{m} / \mathrm{z}=32)$ and $\mathbf{g}-\mathbf{f}$, carbon monoxide and carbon dioxide $(\mathrm{m} / \mathrm{z}=28)$ evolution of cells with an

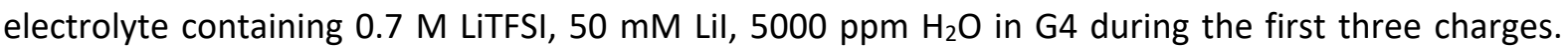
Cells were assembled in an ECC-DEMS cell (EL-CELL) without LICGC protecting the anode and cycled to $70 \mu \mathrm{A} / \mathrm{cm}^{2}$ under $20 \% \mathrm{O}_{2}$ in $\mathrm{Ar}$ and $0 \% \mathrm{O}_{2}$ in Ar during discharge and charge respectively. 


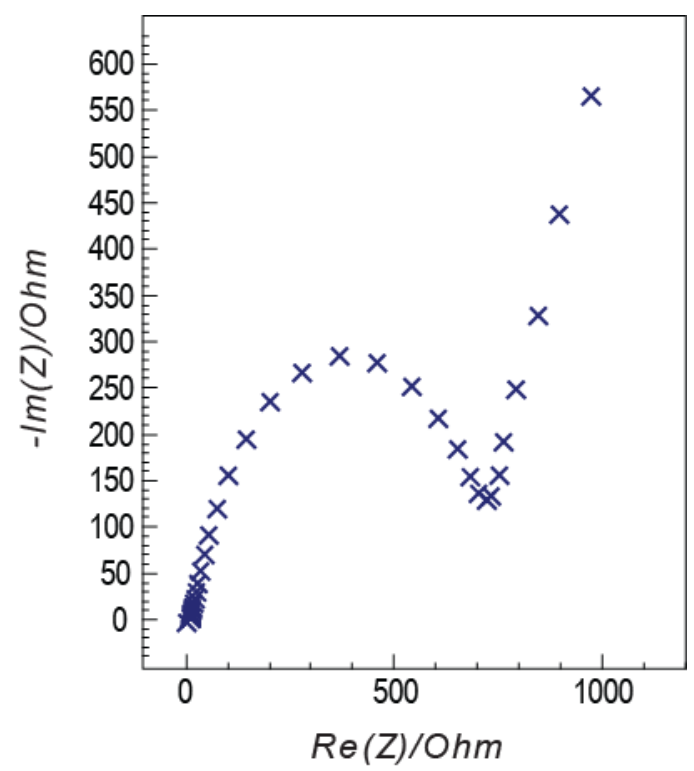

Supplementary Figure 12|Example of electrochemical impedance spectroscopy (EIS) of cells tested in this work used to offset overpotential caused to increased resistance by using LICGC. EIS was normally collected before every electrochemical operation. 
SI Towards reversible and moisture tolerant aprotic lithiu... (700.98 KiB) view on ChemRxiv • download file 
Other files

TOC.bmp (1.40 MiB)

view on ChemRxiv - download file 